\title{
Conceptualisation of speleogenesis in multi-storey artesian systems: a model of transverse speleogenesis
}

\author{
Alexander Klimchouk ${ }^{1}$

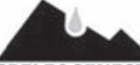 \\ Re-published from: Speleogenesis and Evolution of Karst Aquifers 1 (2), www.speleogenesis.info, 18 pages (ISSN 1814-294X).
}

\begin{abstract}
:
Klimchouk, A. 2005. Conceptualisation of speleogenesis in multi-storey artesian systems: a model of transverse speleogenesis. International Journal of Speleology, 34 (1-2), 45-64. Bologna (Italy). ISSN 0392-6672.

Conceptual and respective quantitative models of speleogenesis/karstification developed for unconfined aquifers do not adequately represent speleogenesis in confined settings. A conceptual model for speleogenesis in confined settings is suggested, based on views about hydraulic continuity in artesian basins and close cross-formation communication between aquifers in multi-storey artesian systems. Soluble units sandwiched between insoluble porous/fissured formations (common aquifers) initially serve as low permeability beds separating aquifers in a confined system. Conduits evolve as result of vertical hydraulic communication between aquifers across the soluble bed ("transverse speleogenesis"). Recharge from the adjacent aquifer is dispersed and uniform, and flow paths across the soluble bed are rather short. There is a specific hydrogeologic mechanism inherent in artesian transverse speleogenesis (restricted input/output) that suppresses the positive flow-dissolution feedback and hence speleogenetic competition in fissure networks, and accounts for the development of more pervasive channelling in confined settings, of maze patterns where appropriate structural prerequisites exist. This is the fundamental cause for the distinctions between cave morphologies evolving in unconfined and confined aquifers and for eventual distinctions of karstic permeability, storage characteristics and flow system behaviour between the two types of aquifers.

Passage network density (the ratio of the cave length to the area of the cave field, $\mathrm{km} / \mathrm{km} 2$ ) and cave porosity (a fraction of the volume of a cave block, occupied by mapped cavities) are roughly one order of magnitude greater in confined settings than in unconfined. Average areal coverage (a fraction of the area of the cave field occupied by passages in a plan view) is about 5 times greater in confined settings. Conduit permeability in unconfined settings tends to be highly heterogeneous, whereas it is more homogeneous in confined settings. The storage characteristics of confined karstified aquifers are much greater.

Recognition of the differences between origin, organisation and behaviour of karst systems evolved in unconfined and confined settings can improve efficiency of exploration and management of various resources in karst regions and adequacy of assessment of karst-related hazards.
\end{abstract}

Keywords: karst aquifers, karst porosity, karst permeability, confined karst, artesian karst, artesian speleogenesis.

Received 2 June 2005; Revised 9 June 2005; Accepted 13 June 2005.

\section{INTRODUCTION}

Despite of widespread recognition of the differences between basic characteristics of unconfined and confined karst aquifers, and between the cave morphologies formed in respective environments, the reasons for this variability are still poorly understood. Interpretations offered so far are contradictory and often misleading.

Traditionally, most of the knowledge about karst and speleogenesis was derived from studies that implied unconfined settings. As a consequence, the widely accepted conceptual models of karst systems rely on a framework of unconfined settings. During last two decades quantitative modelling of early

1- Institute of Geological Sciences,

National Academy of Science, Ukraine

P.O.Box 136, Kiev-30 01030, Ukraine.

E-mail: klim@speleogenesis.info conduit development in limestone (e.g. Dreybrodt, 1990; Dreybrodt and Gabrovšek, 2002; Palmer, 1991, 2000b; Groves and Howard, 1994; Howard and Groves, 1995) have contributed significantly to advancing understanding of the cave pattern formation. However, model configurations and boundary conditions in these studies were chosen to fit conceptual models for unconfined aquifers. Extrapolation of these conceptual models and revealed regularities to the interpretation of features found in confined aquifers can be misleading. Clearly, a conceptual model for karst development (speleogenesis) in confined settings should be drawn which takes into account the specific way in which water is recharged to confined aquifers, stored in them, transmitted through them and discharged from them. This paper further develops previously published ideas (Klimchouk, 1990, 1992, 1997, 2000a) and aims to outline a conceptual model 
for artesian speleogenesis based on views about hydraulic continuity in artesian basins and close cross-formation communication between aquifers in a multy-storey artesian system.

How the mechanisms of enlargement and the resultant cave morphologies differ between unconfined and confined aquifers and result in characteristic distinctions of karstic permeability, storage characteristics and flow system behaviour between the two types of aquifers is discussed. The fundamental cause for these differences is examined and illustrated. Recognition of these differences and improved understanding of the reasons for them is of great practical importance in many fields where adequate concepts about conduit system structure and about karst system behaviour influence effectiveness of resources development, management and protection in karstic regions.

\section{CROSS-FORMATION COMMUNICATION IN ARTESIAN BASINS}

The terms "confined" and "artesian" refer to hydrodynamic conditions and imply that groundwater is under pressure in a bed or stratum confined above and below by units of distinctly lower permeability. The potentiometric surface in such aquifers lies above the bottom of the upper confining bed.

The conventional concept of artesian flow assumes that recharge to confined aquifers occurs only in limited areas where they crop out at the surface (usually at basin margins), and that groundwaters move longitudinally through separate aquifers within the area of confinement. These simplistic views are still commonly adopted in karst studies, which brings about a major problem in interpreting artesian speleogenesis: with a considerable distance and travel time through a soluble rock unit, water should be incapable of significant dissolution in the confined flow area.

Since the middle of 20th century however basinwide hydraulic continuity and close cross-formational communication between aquifers have been acknowledged in mainstream hydrogeology. It is now recognised that there are virtually no impervious rocks or sediments, just large contrasts in permeabilities. Where there is vertical head gradient between aquifers in a layered aquifer system, flow in aquifer beds is predominantly lateral but flow in the dividing beds is predominantly vertical if permeabilities differ by more than two orders of magnitude (Girinsky, 1947). Mjatiev (1947) recognised that the recharge areas of an artesian aquifer are not just the uplifted marginal outcrops, but include all the areas within the basin where the head is lower than in any adjacent aquifers. The concept of basin-wide hydraulic continuity has since become well-accepted and cross-formational communication between aquifers has been described from numerous aquifer and well data (on a local scale), and from basin hydraulics and water-resources evaluation (on a regional scale). Shestopalov (1981, 1988) and Töth (1995) provided important reviews and discussion of these characteristics.

This concept implies more complex flow patterns in artesian basins than were envisioned in the classic view of artesian aquifers (Fig. 1). Besides marginal recharge areas and lateral flow components, this pattern includes laterally alternating recharge and discharge areas (areas of, correspondingly, descending and ascending cross communication) in the confined flow region, superposition of recharge-discharge regimes for particular aquifers in a system, and flow systems at different scales.

Fig. 2 illustrates the flow pattern in a typical multi-storey artesian aquifer system. Recharge to, and discharge from, a given aquifer may take place across dividing beds throughout the whole confined flow area. The amount and direction of hydraulic communication across homogenous dividing beds of low permeability depends on the relationship between the heads of adjacent aquifers, which are, in turn, guided significantly by surface topography. For a given aquifer, there is a gradual vertical transition between net recharge and discharge, which both occur simultaneously. This is why Shestopalov (1981) termed the areas of potentiometric highs and lows respectively the areas of downward (A) and upward

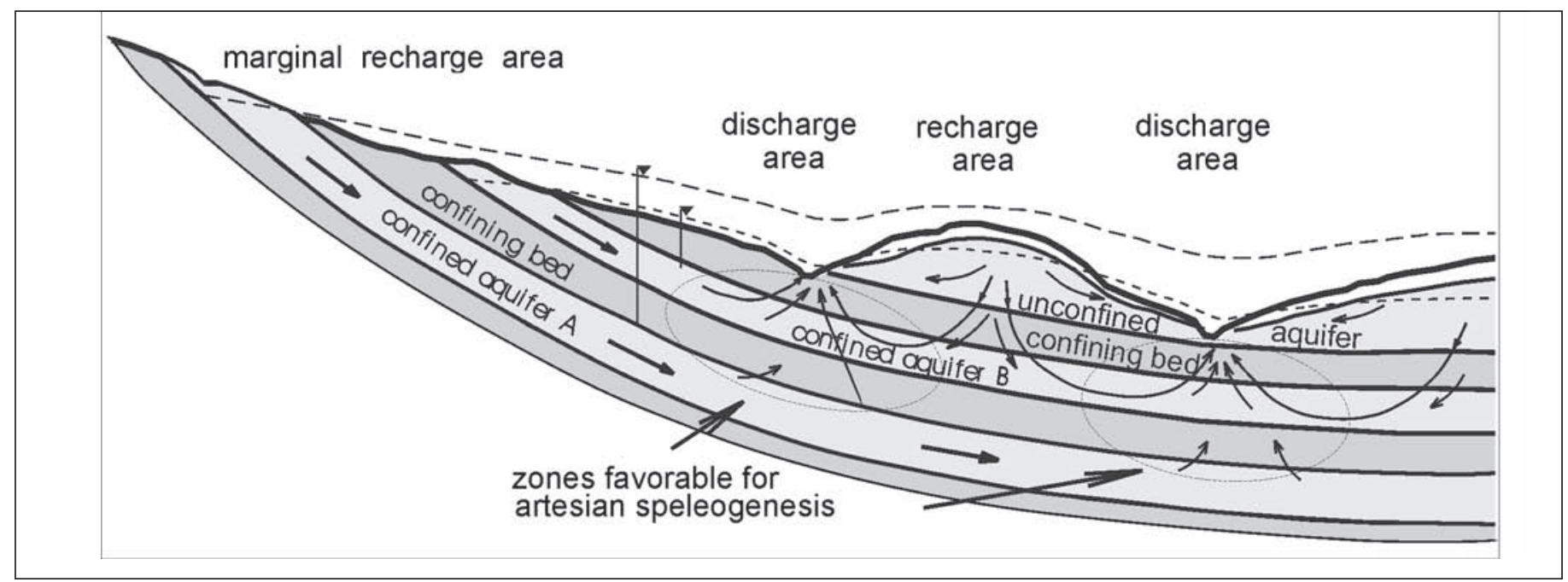

Fig. 1. Flow pattern in a typical artesian basin (From Klimchouk, 1997). 
(B) percolation. Potentiometric highs correspond to topographic highs, whereas potentiometric lows coincide with topographic lows, most commonly river valleys.

In addition to vertical head gradients, heterogeneous vertical permeabilities through the confined flow area exert a strong guidance over cross-formational flow between aquifers. Cross-formational flow can be greatly enhanced in areas where permeabilities across a dividing bed are locally elevated due to the presence of zones of enhanced fissure frequency and fault zones, etc. Such a situation is commonly represented by erosional valleys, as they normally develop along zones of weakness and induce potentiometric lows in the underlying confined aquifers. This is why erosional valleys and other prominent topographic lows are important in determining zones of preferential artesian speleogenesis, even in the deep parts of basins.

In basins where stratigraphically lower aquifers crop out along marginal recharge areas at higher elevations and where heads are generally great (as in high-relief cratons and foreland basins), vertical head gradients between aquifers are predominantly upward, so that pattern of upward communication prevails throughout the entire area of confined flow. Again, local topographic lows (valleys) impose increased head gradients so that crossformation communication and the combined discharge from the artesian system are commonly maximised in such areas. Basinal flow patterns of this type are well represented by the Wyoming and Arizona foreland basins, as illustrated by Huntoon (1993, 1996).

Cross-formational hydraulic communication is one of the most important factors determining the resources and chemical composition of groundwaters in the upper hydrogeodynamic storey of artesian basins. Rates of vertical water exchange depend not only on permeabilities, thicknesses, continuity and number of dividing confining beds, but also on the tectonic regime of a region. The uplift trend and the neotectonic activity favour crossformational communications between aquifers.

The concept of crossformation hydraulic communication has been largely overlooked in karst hydrogeologyand speleogenetic studies. It obviously has an immense importance, and provides a broad perspective for speleogenetic implications.

Fig. 2. Flow pattern in a multi-storey artesian aquifer system (From Shestopalov, 1989).

$1=$ aquifer,

$2=$ low permeable dividing bed,

$3=$ piezometric levels,

$4=$ directions of groundwater flow. 


\section{CONVERSION OF HYDROGEOLOGIC FUNCTIONS OF SOLUBLE BEDS IN AN ARTESIAN SYSTEM}

Artesian basins containing carbonate and sulphate formations are widespread throughout cratonic and foreland regions. The hydrostratigraphy of an artesian basin is determined mainly by the relative permeabilities of rock units. Aquifers are separated from each other and from any upper unconfined aquifer, by lowpermeability beds. Initial permeabilities of common aquifers (e.g. many medium- to coarse-grained clastic sediments and fissured rocks) are normally greater than that of soluble rocks such as massive limestones or sulphates prior to speleogenesis. Soluble units are commonly sandwiched between formations with initially higher permeability so they serve as separating beds (aquitard) in a confined system. However, they change their hydrogeologic role to karstic aquifers in the course of speleogenetic evolution.

As late diagenesis and tectonism impose fissure permeability, soluble units increasingly transmit groundwater between "normal" (non-karstic) aquifers in zones of sufficient head gradient. According to the Girinsky premise, flow in such dividing beds is predominantly vertical. When conduit systems have developed within soluble units, conventional karst wisdom views the situation as a karst aquifer sandwiched between aquitards, without recognising that the initial conditions were quite the opposite.

Most thick soluble rock sequences include a combination of layers of varying permeability. Beds of higher initial porosity and relatively diffuse permeability (such as oolitic beds) may exist within an otherwise massive and poorly fissured carbonate sequence. They will act as aquifers, and hydraulic communication across dividing beds will improve with time through speleogenesis. More complex relationships occur in thick, lithologically heterogeneous sequences, composed, for instance, of intercalated carbonate, sulphate, and clastic beds. Switching of hydrogeological functions of different beds in a sequence during the speleogenetic evolution of the soluble ones is quite common in artesian settings (Lowe, 1992; Klimchouk, 1992, 1994, 1997). This is because changes in permeability of soluble units through time are much more dynamic and drastic than that in non-soluble beds.

Lateral transmission of groundwaters in artesian basins occurs mainly through original non-karstic aquifers. It is important to recognise that because speleogenesis in layered artesian systems evolves in response of transverse flow across soluble dividing beds, the resultant conduit systems, even when mature, never provide for significant lateral hydraulic connection at the basin scale. Even the largest maze systems in the soluble beds have continuous lateral extent through a few $\mathrm{km} 2$ as a maximum, for few hundreds meters in any single direction. In the lateral aspect they remain isolated clusters rather than systems laterally connecting recharge and discharge areas.

\section{DISSOLUTION MECHANISMS}

A common view that artesian conditions offer limited hydrodynamic and chemical potential for karstification is based on the deeply-rooted but generally inadequate simplistic concept of lateral through-flow in soluble beds, viewed as aquifers in an artesian basin. In contrast, transverse hydraulic communication between formations of different lithology and zones with contrasting geochemical environments or different physical conditions supports the operation of a great diversity of dissolutional mechanisms that may form caves under artesian settings.

Within confined areas cross-formational flow is predominantly ascending, being most intense in areas underlying prominent topographic lows, such as large river valleys. Aggressive recharge to soluble units in confined settings comes from the underlying aquifer formations. Recharge can be evenly distributed across considerable areas, which favours the formation of maze patterns, or focused locally along highpermeability pathways such as fault zones.

Aggressiveness in most cases represents an original undersaturation of groundwater with respect to the solid phase that is being entered, such as in the case of low-sulfate waters from underlying carbonates entering a gypsum bed, or waters undersaturated with respect to calcite from sandstone or sand beds entering a limestone bed. It can also reflect acquisition of new sources of acid (e.g. by oxidation of hydrogen sulphide), or be due to a number of mechanisms that rejuvenate dissolutional capacity of fluids, such as mixing of groundwaters of contrasting chemistry, cooling of water, sulfate reduction and dedolomitization (Palmer, 1995).

Carbonic acid dissolution, which dominates overwhelmingly in unconfined carbonate aquifers, also operates as a hypogenic agent, though the origin of the acidity is different. It can be related to $\mathrm{CO} 2$ generated from igneous processes, to thermometamorphism of carbonates, or to thermal degradation and oxidation of deep-seated organic compounds by mineral oxidants. Creation of significant caves by hypogenic carbonic acid depends mainly upon rejuvenation of aggressiveness by mixing, or by a drop in temperature. The latter mechanism is distinguished as hydrothermal speleogenesis, occurring in highgradient zones where ascending flow is localised along some highly permeable paths.

Dissolution of carbonates by hydrosulfuric acid is another important speleogenetic process in deepseated anoxic environments where there are sufficient sulfate sources for reduction and where the H2S generated can escape from the reducing zones settings typical of the margins of sedimentary basins containing evaporate formations.

In shallower conditions, where H2S-bearing waters rise to interact with oxygenated meteoric groundwaters, sulfuric acid dissolution can be a very strong speleogenetic agent. Substantial sulfuric acid dissolution can also be caused by oxidation of metallic sulfides such as pyrite, where it is localised in ore bodies or along certain horizons or bedding planes. 
Dissolution in deep-seated settings is believed to be slow, due to the generally sluggish circulation and, hence, to mass balance restrictions. Even in this case artesian speleogenesis, being operative throughout prolonged geological times, is generally important for cave inception sensu Lowe (1992), that is the opening up of pathways for further, more effective, circulation. However, the mass balance restrictions are not severe where continuing uplift brings stratified confined aquifer system closer to the eroding surface and thinning and local breaching of upper confining beds increases hydraulic gradients across the system and greatly intensifies cross-formational circulation through dividing soluble units, increasingly leaky "aquitards".

\section{CONFINED VS. PHREATIC CONDITIONS}

The term "phreatic" refers to conditions where water saturates all voids in a rock or sediment, in contrast to vadose conditions, above the water table, where voids are water filled only temporarily, if ever. In this sense phreatic conditions are similar to confined conditions. Moreover, water in phreatic conduits is always confined by the host rock and possesses some hydraulic head above the conduit ceiling. This has given rise to some confusion where the terms "phreatic" and "artesian" ("confined") have been misleadingly understood as being equivalent, especially where bathyphreatic conditions are concerned. For example, Glennie (1954) termed water rising from such deep phreatic paths "artesian". Jennings (1971, p.97) noted that such usage is in a strict sense incorrect, but it serves as a reminder that consolidated rock can act virtually as its own aquiclude.

Klimchouk (2000a) suggested to limit usage of the term "artesian" ("confined") to prevailing flow conditions in an aquifer (or a system of aquifers where there is major geologic confinement), rather than to flow conditions within a single conduit. Use of the term "phreatic" should be restricted to the lower zone in unconfined aquifers, limited above by a water table that is free to rise and fall.

The speleogenetic importance of the distinction between phreatic and confined conditions has not been fully recognised in karst science until recently. Within unconfined phreatic conditions, discharge through a developing flow path is governed by the resistance of the path itself, particularly that of its narrowest part. Discharge increases with the growth of the conduit, more dramatically after breakthrough, until the amount of available recharge begins to limit the flow (Palmer, 1984, 1991). In confined conditions, discharge through a conduit depends on its diameter only before breakthrough, after which it is governed mainly by hydraulic conductivity of the source aquifer (inflow control) or by resistance of the least permeable bed in the down-gradient direction (confined outflow control). This point is examined later in detail.

\section{TRANSVERSE VS. LATERAL SPELEOGENESIS}

The conventional approach to speleogenesis implies that groundwater flows laterally through an aquifer, from a recharge boundary to an output boundary. This applies either to unconfined settings (with the exception of the vadose zone) and to confined settings within the "old" simplistic artesian concept. Furthermore, it is commonly implied that water flows along the long dimension of a fissure, which is commonly lateral relative to bedding (Fig. 3A), or along a pathway that combines long dimensions of several laterally connected fissures. Long flow lengths and therefore low discharge/length ratios (sensu Palmer, 1991), particularly during the early stages

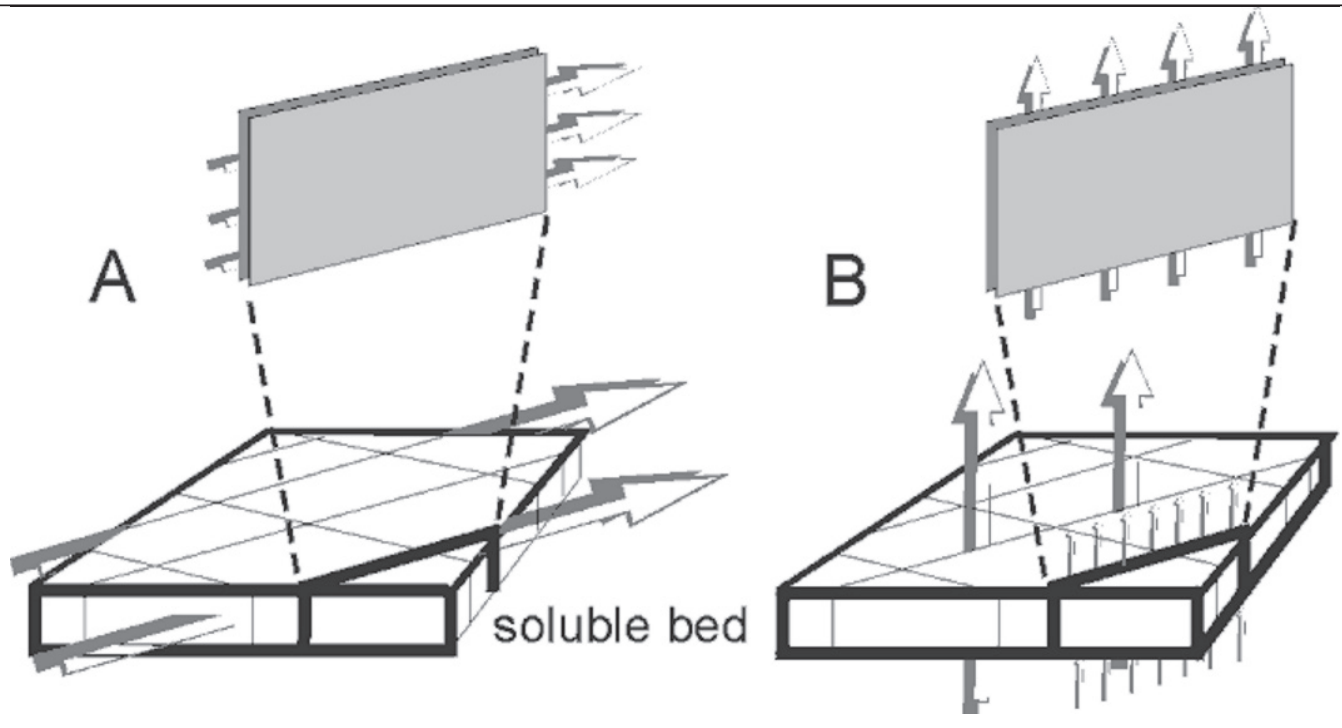

Fig. 3. A diagram illustrating general concepts of lateral $(A)$ versus transverse (B) flow through a single fissure and a fissure network encased in a soluble bed. See also Fig.4. 
of speleogenesis, are inferred in such configuration which is commonly used in modelling of early conduit development. Similarly, the parameter of passage length, or cave development, derived from speleological mapping, tacitly implies the meaning of the length of flow that formed a passage. Such views represent what can be called lateral (or longitudinal) speleogenesis, a concept that is generally adequate when applied to unconfined settings. It is deeply rooted in the speleogenetic literature and is commonly extended to encompass speleogenesis in confined settings, resulting in misleading implications.

It has been shown above that vertical hydraulic communication across soluble beds is predominant in multi-storey artesian systems. However, the conventional concept of lateral speleogenesis does not seem to adequately reflect arrangement of flowpaths in this case. A concept of transverse speleogenesis has been suggested (Klimchouk, 2000a) to describe conduit development in a soluble bed sandwiched between aquifers in multi-storey artesian systems.

Where vertical, commonly upward, circulation occurs through a fissured soluble bed, which is treated as a leaky aquitard, flow actually follows along a fissure height (Figs 3B and 4A), or along a sequence of heights of vertically connected fissures (Fig.4A). Flow distances through a soluble rock are rather short, commonly of orders of meters or a few tens of meters, thus allowing rather high discharge/length ratios. Where laterally continuous fissure networks are present and exploited by transverse speleogenesis, maps of caves formed in this way may display tens or even a few hundred kilometres of integrated passages. The flow length is conventionally associated with the length of some laterally continuous series of passages across a cave field, which can be hundreds of meters or a few kilometres, but these figures have nothing to do with the actual flow pattern and flow length through the soluble unit.

Transverse speleogenesis denotes conduit development driven by the vertical head gradient across a soluble bed so that flow is directed transversely relative to bedding, stratiform fissure networks and the long dimensions of intrastratal fissures (Fig. 3B and 4). In this concept uniform aggressive recharge to all fissures available at the lower contact and short flow paths in a soluble unit are of primary importance. In the case of transverse speleogenesis, laterally extensive cave systems do not imply long conduit flow paths.

A single fissured bed of small thickness can occur

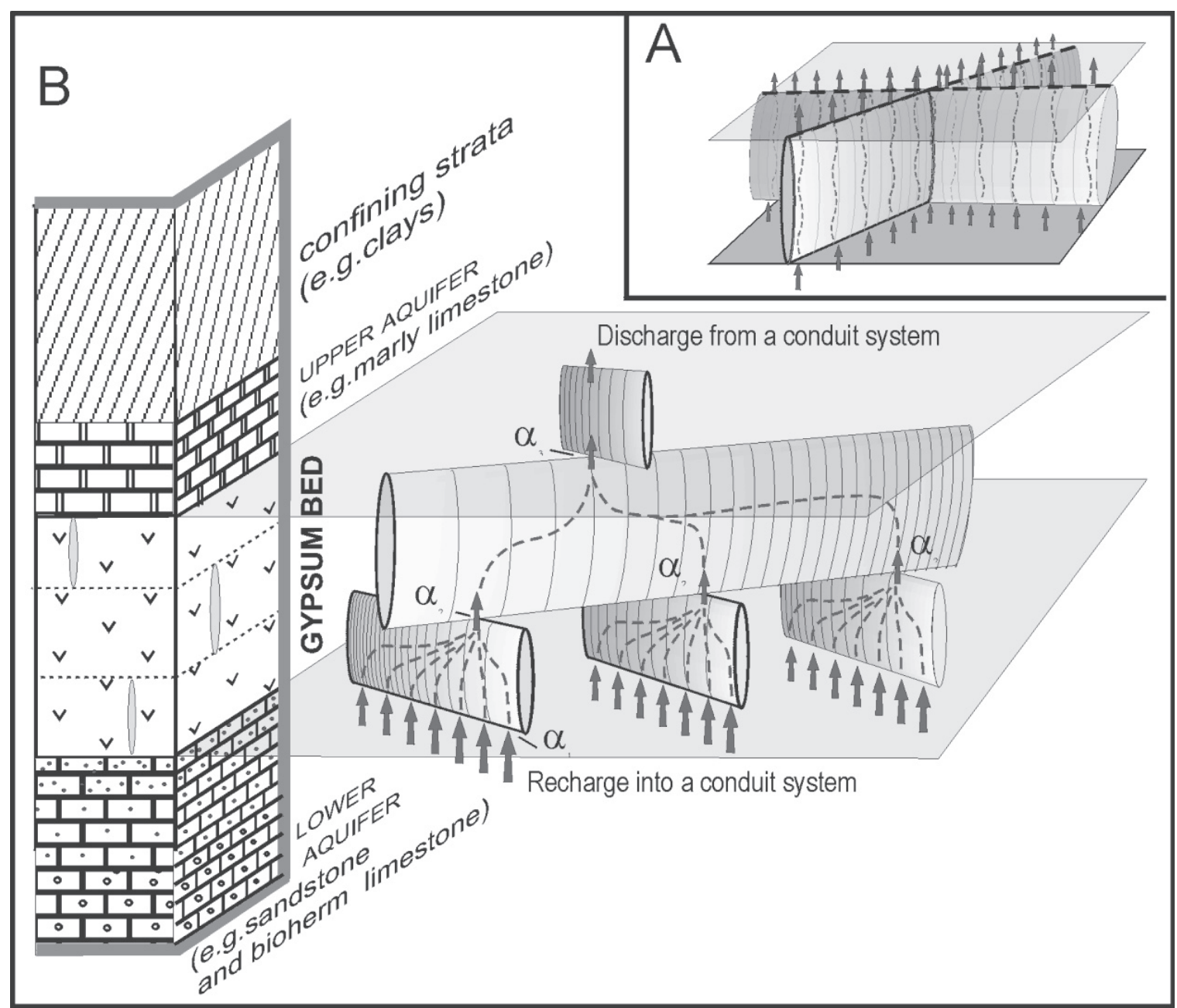

Fig. 4. $\mathrm{A}=$ Transverse flow through a fissure network in a single level, with fissures crossing a bed for the whole thickness; $\mathrm{B}=$ transverse flow through fissure networks in multiple levels. Litho- and hydrostratigraphy depicted corresponds to the case of the Western Ukraine, although such multi-level arrangement of fissure networks is common for stratified carbonate and sulfate sequences. 
sandwiched between diffuse aquifers, in which each fissure directly connects the bottom and top boundaries (Fig.4A). More commonly, there are several beds or horizons of varying character within a soluble unit, each horizon encasing a largely independent fissure network (Fig.4B). Fissures along a given horizon are rarely co-planar with fissures of an adjacent horizon, but they may have vertical connections at discrete points. Moreover, fissure frequency may differ between horizons. Such discordance in permeability structure between horizons causes some lateral component in the generally transverse flow. The same effect is caused by discordance in permeability structure and values between the lower and upper aquifers. Because of the lateral component, the morphology of passages on some master levels can be shaped correspondingly, giving a misleading impression of a generally lateral flow through a soluble unit. Multi-storey (threedimensional) maze caves with stratiform levels formed in this way may have tens to a few hundreds of kilometres of laterally integrated passages, which further favours the misleading interpretation that they developed laterally.

\section{THE MECHANISM OF TRANSVERSE SPELEOGENESIS}

As demonstrated by numerous quantitative modelling studies, speleogenesis in unconfined settings tends to produce broadly dendritic patterns of channels due to the development of competing flowpaths. Such development occurs because the positive feedback relationship between dissolution rate and discharge causes accelerated growth of selective favourable paths. Discharge increases with the growth of the conduit before and, more dramatically, after breakthrough. Discharge through a developing conduit is governed by the resistance of the conduit itself, by its narrowest (downgradient) part in particular, until the amount of available recharge begins to limit the flow.

Transverse speleogenesis in the confined settings as depicted above proceeds through an essentially different mechanism. After breakthrough, the rate of conduit enlargement does not increase dramatically because the vertical hydraulic gradient along the successful path quickly diminishes. As the hydraulic resistance of the conduit becomes smaller than that of the aquifers, discharge through the conduit is controlled by the hydraulic conductivity of the aquifers and by the boundary conditions, but no longer by the diameter of the conduit. Unless and until the boundary conditions change, the flow rate and the enlargement rate in the conduit remain constant at some level. The positive feedback loop is no longer the determinant of conduit development. Moreover the growth of alternative transverse proto-conduits does not languish, as would happen in unconfined settings after the breakthrough in the winner conduit. Because the vertical head gradient between the aquifers is still maintained, although diminished, at some lateral distance apart from the successful conduit, alternative conduits continue to grow and eventually reach breakthrough, either to the downgradient aquifer or laterally to the conduit that had been "broken through" earlier. This is a hydrogeologic mechanism that suppresses the speleogenetic competition in a network and favours to development of maze patterns in confined settings where appropriate structural prerequisites exist.

The conceptual model of transverse speleogenesis has been developed intuitively (Klimchouk, 1990, 1992, 1994, 1997, 2000a), based on extensive field observations in caves of various regions, but most of all in the giant gypsum caves of the Western Ukraine (Klimchouk, 2000b), which provide probably the most instructive field area for studying artesian speleogenesis. The validity of this conceptual model has been recently supported by numerical modelling for the case of gypsum bed sandwiched between aquifers in an artesian system (Birk, 2002; Birk et al., 2003). This study provided useful insight into functional relationships between conduit growth and various hydrogeologic parameters and demonstrated the dependence of the general structure of evolving cave systems upon these parameters. Although the model set-up was only a rough approximation of natural settings found in the Western Ukrainian gypsum karst, the model simulation gave a good agreement with field observations. In particular, it was found that the formation of multi-storey maze structures is favoured:

- by the presence of systematic heterogeneities in vertical conductivity of a fissure system. These are represented in reality by discordance in permeability between fissure networks at various intervals, or between fissure networks and the adjacent aquifers (Klimchouk, 1992, 2000b; Klimchouk et al., 1995). This discordance determines imperfect vertical connectivity between fissure networks occurring in different intervals, producing the effect somewhat similar to that of the presence of low permeable intercalations (see Fig. 4B, where term a indicates varying exchange coefficients between permeability structures occurring at different levels);

- by the presence of a low permeable layer at the top of the soluble unit which restricts the vertical flow to a degree. In fact, in field examples known to the author it is quite common for the permeability of the immediately overlying (receptacle) aquifer to be considerably lower than that of the lower (feeding) aquifer;

- by the variation of boundary conditions in time, as in the case of increasing hydraulic gradient across the soluble unit due to incision of the river into the upper confining bed and increase of leakage from the system. The importance of changing boundary conditions to artesian speleogenesis, in response to uplift and incision of valleys, was discussed earlier in Klimchouk (2000a).

Palmer $(1991,2002)$ suggested that maze caves could form only if the growth rate is similar in many alternate flow paths. He further specified that this can happen only if all passages reach breakthrough conditions quickly and hence the maximum enlargement rates controlled mainly by kinetics, which is favoured by 
the high ratio of discharge to flow distance $(\mathrm{Q} / \mathrm{L})$.

The configuration of the transverse speleogenesis model implies generally high $\mathrm{Q} / \mathrm{L}$ ratios because the length of flow across a soluble unit is short and hydraulic gradients across it are relatively high. However, the importance of this condition for artesian transverse speleogenesis is probably limited because similarity of growth rates after breakthrough is achieved by switching of control over discharge to the hydraulic conductivity of one of the adjacent aquifers before the maximum growth rates could be reached. When time-variant boundary conditions change to increase flow through the system (as in case of local breaching of artesian confinement), many alternate conduits, being already initiated, would exhibit high $\mathrm{Q} / \mathrm{L}$ ratios and maximum enlargement rates. However, this would be the development of already established structure rather than the effect of establishing the pattern structure. The question about importance of high $\mathrm{Q} / \mathrm{L}$ ratios to the development of maze patterns in artesian transverse speleogenesis needs in further analysis and modelling evaluation.

From the above consideration it is concluded that there is a specific hydrogeologic mechanism inherent in artesian transverse speleogenesis (restricted input/ output) that suppresses the speleogenetic competition in fissure networks and accounts for the development of more pervasive channelling in confined settings, of maze patterns where appropriate structural prerequisites exist.

\section{ARTESIAN SPELEOGENESIS CONTROVERSY AND THE PROBLEM OF MAZE CAVES IN THE LIGHT OF THE TRANSVERSE SPELEOGENESIS CONCEPT}

Authors that previously attributed the origin of maze caves to artesian conditions (e.g. Howard, 1964; White, 1969; Ford, 1971, Huntoon, 2000) or disregarded this possibility (Palmer, 1975, 1991, 2000a), all implied the "classical" concept of lateral artesian flow through a soluble unit. Palmer examined the hydraulickinetic conditions within a simple loop in which water diverges into two branches that rejoin downstream, and showed that these branches will not develop at comparable rates except at very high $\mathrm{Q} / \mathrm{L}$ ratios. Such conditions are not characteristic of lateral artesian flow, so he concluded that slow groundwater flow near chemical equilibrium, typical of confined aquifers, is least likely to produce maze caves (Palmer, 2000a).

White (1969) described the type of a "sandwich aquifer", where a thin carbonate unit is overlain and underlain by insoluble strata. He noted that network caves are characteristic for this situation and pointed out that such patterns form due to the lack of concentrated recharge from overlying beds.

Palmer (1975) specifically addressed the problem of maze patterns and distinguished two main settings favourable for their development: 1) high-discharge or high-gradient flow during floods in the vicinity of constrictions in the main stream passages (floodwater mazes) and, 2) diffuse recharge to a carbonate unit through a permeable but insoluble caprock such as quartz sandstone. Later he added the cases of sustained high gradients, such as beneath dams, and of mixing zones where the groundwater aggressiveness is locally boosted, and generalised that the formation of maze caves requires high $\mathrm{Q} / \mathrm{L}$ ratios (Palmer, 2002). Evidences for the floodwater high gradient mechanism are abundant and commonly unambiguous but the mechanism of diffuse recharge through a permeable but insoluble caprock requires additional discussion.

Maze origin by diffuse recharge through a caprock has been substantiated theoretically (see Palmer, 2000 for specific analysis) and supported by numerical modelling by Clemens et al. (1997). It was suggested for unconfined settings (downward infiltration through a caprock), although Palmer (1975) noted that most caves used as evidence have been interpreted by previous workers to be the result of artesian flow confined beneath the insoluble rock. It should be pointed out that regardless of the type of flow system and direction of vertical communication, this mechanism contains an important idea about the governing role of an adjacent porous formation for the amount of flow to fissures in a soluble unit (also expressed by White, 1969). This is the mechanism of restricted input/output that suppresses the positive flow-dissolution feedback and hence speleogenetic competition. It has been shown above to be characteristic (although probably not unique) for artesian transverse speleogenesis.

This mechanism can be operative in the settings of unconfined flow and downward infiltration through a soluble unit, although in many instances this interpretation can be misleading. Palmer used several reasons to substantiate the origin of network caves by infiltration through an insoluble caprock. However, each of them appears to leave room for an alternative interpretation within frame of the artesian transverse speleogenesis concept if one appreciates the fact that modern unconfined settings in shallow sections of stratified sedimentary sequences are the result of erosional opening of the formerly confined aquifer system, in which hydrostratigraphic arrangement could have been different than it appears today. A permeable caprock in many cases could have been an artesian aquifer beneath confining strata, now stripped. The carbonate bed could initially serve as an aquitard separating confined aquifers. The peculiarities of localisation of network mazes can be easily interpreted in terms of zones favourable for cross-formation flow, hence for initiation of transverse conduit system. Morphological evidences for unconfined origin, such as scallops indicating high flow or fluting of walls by descending water could be features superimposed on the artesian passage morphology during subsequent unconfined phreatic and vadose development. Additional criteria specific for transverse speleogenesis should be used to differentiate between the two possibilities, see below for details.

There is also a more general reason in favour of maze development by artesian transverse mechanism rather than by downward recharge through the 
caprock. The latter emphasises the mode of recharge but implies that flow in the soluble unit is generally lateral. However, true mazes demonstrate remarkable consistency of passage morphology and size through area, which points to a consistency of hydrochemical conditions during their formation. This condition is not met in the scheme of lateral flow through a soluble unit but it is inherent to the transverse speleogenetic concept.

Huntoon (2000) attributed the differing organisation of unconfined and confined conduit networks to the degree of saturation, e.g. to difference in the volume of rock interacting with solvent. He suggested that 2and 3-dimentional mazes form in confined aquifers because they are fully saturated, thus maximising the volume of rock interacting with solvent and favouring to ubiquitous dissolution. However, this reason alone cannot account for the distinctions in conduit organisation between unconfined and confined settings. In fact, dendritic patterns typical of unconfined settings originate in the phreatic zone, where aquifers are also fully saturated.

Maze cave origin is frequently attributed to hydrothermal speleogenesis, the tendency reinforced by the paper by Bakalowicz et al. (1987) which suggested hydrothermal origin for the Black Hill mazes. Other known examples of rectilinear mazes for which hydrothermal dissolutional mechanism is well established are caves in the Buda Hills in Hungary (Dublyansky, 2000). However, an emphasis on hydrothermal dissolutional mechanisms should not obscure the fact that these caves are attributed to a confined flow system, more specifically to thermal flow rising across stratified carbonate sequences (Fig.5). Lateral component of flow and cave development was induced due to the presence of low permeable beds and due to similar effects from discordance in fissure patterns occurring at different levels, as discussed in the previous section.

Frequent association of maze caves and hydrothermal systems can be easily explained by taking into account that deep basinal flow is commonly heated. Where structural and hydrodynamic conditions allow upward cross-formational flow, this generally creates high-gradient thermal anomalies that favour to hydrothermal dissolution. However, the origin of maze patterns is attributive not to hydrothermal dissolution but to hydraulic conditions that favour disruption of discharge-dissolution feedback mechanism. It was shown above that a number of dissolutional mechanisms can be operative in artesian transverse speleogenesis but none of them appear to specifically account for development of maze patterns. However, it was recently hypothesised (Dumont et al., 1999) that the retrograde solubility of calcite coupled with heat transfer from the fluid to the rock provides the mechanism by which dissolutional power is distributed among all competing flow paths to form maze patterns. Details were not reported in that short abstract.

Some elements of the artesian transverse speleogenesis concept were adopted by Ford when he distinguished the type of artesian caves with basal injection (1988) and proposed the "lifting" origin for the Black Hill mazes (1989; see Fig.5), drawing analogies with the great gypsum mazes of the Western Ukraine. Many details of morphogenetic discussion in the latter work fit well to the concept of transverse speleogenesis, as described above.

The above brief review demonstrates that the longlasting discussion of the possibility of the artesian origin of maze caves can be satisfactory resolved on the basis of the proper recognition of cross-formational hydraulic communication in artesian basins, and of the concept of transverse speleogenesis. Adoption of these views bypasses the major problem that existed in interpreting artesian speleogenesis, i.e. limited hydraulic and hydrochemical cave-forming capability of the "classic" lateral artesian flow.

The broad evolutionary approach to speleogenesis implies that caves may inherit prior development through greatly changing settings. Hence, the problem of cave origin requires specifying the mechanisms that are operative, and the features produced, during each of the main stages. The skeletal outline of a cave pattern is perhaps the most definite feature that can be attributed to certain recharge modes and flow systems (Palmer, 1991). As confined settings commonly pass into unconfined ones, phreatic through vadose, each subsequent setting may contribute substantially to cave development, sometimes adding the majority of a cave space (see more about artesian and post-artesian evolution in Klimchouk, 2000a). However, unless the original pattern has altered dramatically, many caves can be still placed in the artesian class, although subsequent effects should be properly acknowledged.

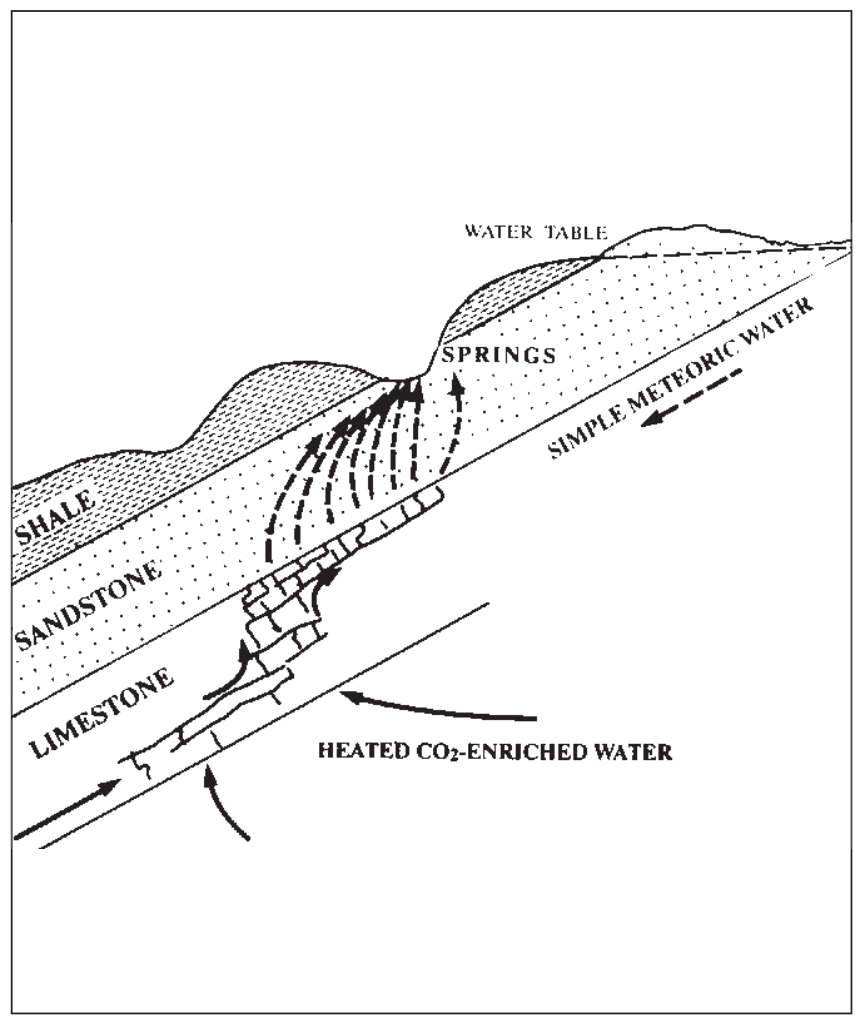

Fig. 5. A hypothetic model of the origin of "lifting" mazes suggested for the caves of the Black Hills, South Dakota (Adopted from Ford, 1989). 


\section{CRITERIA OF THE ARTESIAN TRANSVERSE ORIGIN FOR CAVES}

The following geologic, morphologic and sedimentologic criteria are, in combination, indicative of the artesian transverse speleogenesis:

1. Presence of an underlying aquifer. In most cases there is an insoluble porous or fractured bed, such as quartz sandstone or sand, immediately beneath the soluble unit, which is a regional aquifer and the source of water for transverse speleogenesis. It can contain less soluble material than the cave-bearing unit, such as in case of oolitic limestone or dolomite underlying gypsum. To provide for dispersed and uniform recharge to the soluble bed, the permeability structure of the source aquifer should be much more densely spaced than fissures in the soluble unit;

2. Presence of an overlying aquifer. It can occur immediately above the soluble unit, or be separated by thin leaky aquitard. It acts as a governor for outflow, and allows transverse speleogenesis in a soluble bed to occur through areas located away from major flowpaths or breaches that discharge water out from the artesian system. The upper aquifer can be of lower permeability that the lower aquifer. In some cases there can be no overlying aquifer, just an aquitard above, which should be considerably leaky to favour transverse speleogenesis in a soluble unit;

3. Presence of a confining stratum. The confining formation is commonly of regional extent and is composed of material with a low permeability. Transverse speleogenesis operates where the thickness or the confining strata is reduced due to erosional incision that induces considerable leakage, or where faulting or stratigraphic weaknesses provide for discharge from the system;

4. Stratiform fissure systems in a soluble formation. Laterally extensive fissure systems with rather uniform spacing, encased in a single bed or in a horizon comprising few beds, are common in stratified strata throughout cratons. When a soluble sequence consist of several beds, fissure systems can superimpose to create pre-requisites for multi-storey maze caves. Transverse speleogenesis can generate single isolated passages or clusters of few intersecting passages where fissures are scarce and not well connected laterally;

5 . The overall layout of cave systems and position of entrances shows no genetic relationship to modern landscapes. However, active and significant cave growth is normally induced by, and converges toward, valleys incising into upper confining formations. Where modern valleys have incised below the cave hosting formation, caves tend to border them. Paleovalleys, often buried, that cross modern watersheds could induce transverse speleogenesis beneath them so that cave systems can be found in the internal parts of modern intervalley massifs;

6. Cave patterns resulting from transverse speleogenesis are strongly guided by the fissure pattern in a soluble bed (or a composite unit), and influenced by heterogeneities of permeability structure in the adjacent formations and by the overall hydrostratigraphic arrangement. Passages that hold similar positions in the network relative flowpath arrangement (guided by the same set of joints, or occurring within a single cave series or at the same storey) are uniform in size and morphology. Two- or three-dimensional (multi-storey) rectilinear network mazes are typical with no clear trends in passage size and morphology throughout labyrinths. A common feature of network mazes is high passage network density (see section below). Spongework mazes are not typical, because they are guided by intergranular pores rather than by fissures, and pores are generally not capable to create regular network of initial transverse paths through a soluble bed;

7. The characteristic features of artesian transverse cave networks are numerous blind terminations of passages (Fig. 8, photos C, D and E). They were always a puzzling feature for researchers guided by the conventional speleogenetic concept, which implies that passages are formed by lateral flow through them. According to the concept of transverse speleogenesis even a single, laterally isolated fissure can enlarge to a passable size, remaining blind-terminated at both ends (see Fig. Fig 11-IC);

8. Among medium-scale morphological features of artesian transverse mazes some bear specific hydrologic functions and thus can be particularly indicative of a transverse origin (Fig. 6), these are:

a) Feeders: the lowermost components in a system, vertical or sub-vertical conduits through which water rose from the source aquifer (Figs 7 and 8). Such conduits are commonly separate but sometimes they form small networks at the lowermost storey of a system. Feeders join master passages located at the next upper level and scatter rather uniformly through their networks. Where master networks occur at the base of a soluble bed, they can receive recharge through the entire length of fissures. In this case passages demonstrate rift-like extensions at their lower parts, which extend down to the contact with the underlying aquifer bed (Fig.7, A, B, D, E). Feeders are commonly obscured by the presence of sediment fill, or misinterpreted as "swallowing" or entrenchment forms rather then forms that conducted rising flow;

b) Masterpassages (in multi-storey mazes): stratiform passages that constitute laterally extensive networks within certain horizons of a soluble unit (Fig.9). They receive dispersed recharge from numerous feeding channels and conduct flow laterally to the nearest outlet feature or to the connections with still upper storeys. Considerable lateral flow component at the level of master passages causes that their size is commonly larger than that of passages on other storeys.

c) Outlet features: domes, cupolas, and vertical channels (domepits) that rise from the ceiling of the uppermost passages, or from master passages, to the bottom of the overlying bed. They discharge water from cave systems to the overlying aquifer (Fig.10).

9. Natural convection mechanisms, driven either by thermal of density differences, are widely operative 


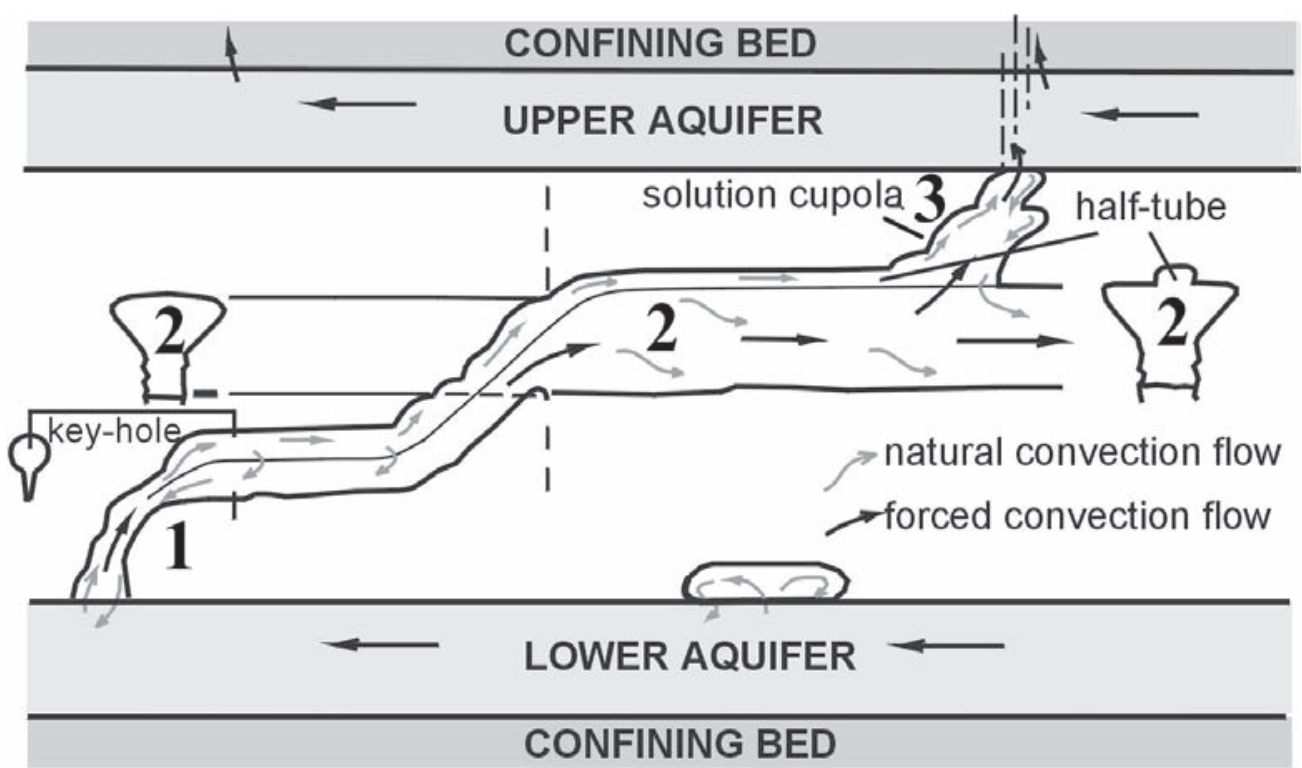

Fig. 6. Typical morphogenetic features of maze cave of artesian transverse origin shown at their hydrologic functionality (on an example of the Western Ukraine): 1 = feeder channels; 2 = master passages; 3 = outlet features.
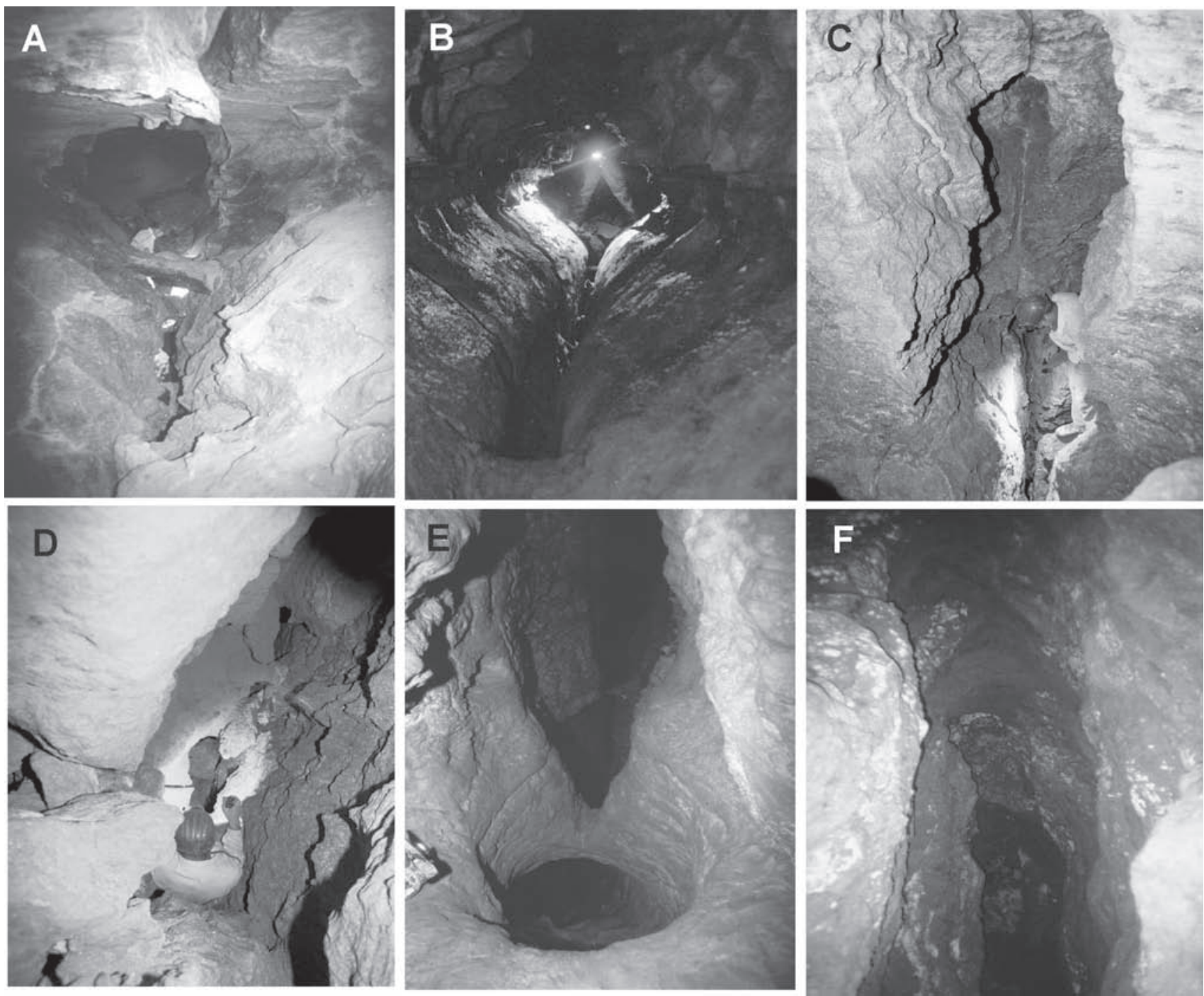

Fig. 7. Examples of feeder conduits from artesian caves. A, B, D and E show feeders as rifts at passage bottoms. They are frequently misinterpreted as vadose trenches. $\mathrm{D}$ shows feeder hole at the bottom of the rift (view straight downward). $\mathrm{C}$ and $\mathrm{F}$ show feeders that join master passages from a side, and C represents a small "blind-ended" passage. A, C, D - Mlynki Cave in gypsum, Western Ukraine; B - Knock Fell Caverns in limestone, UK; E - Fuchslabyrinth Cave in limestone, Germany; F - Estremera Cave in gypsum, Spain. Photo by the author. 


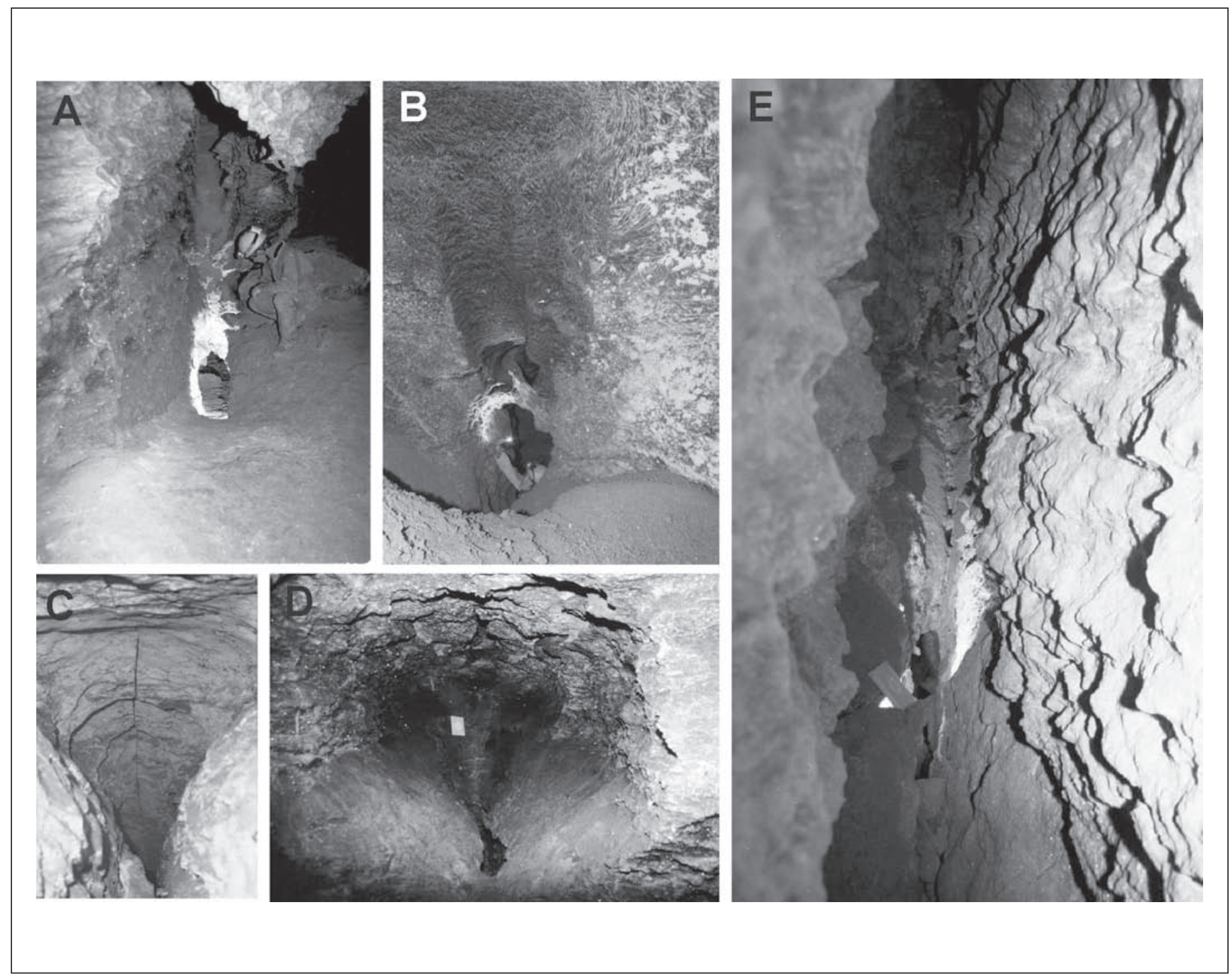

Fig. 8. Examples of feeder conduits from artesian caves. A and B show feeders that join master passages from a side. C, D and E show feeders at "blind-ended" passages. A and E - Mlynki Cave, B and D - Optymistyshna Cave, and C - Ozerna Cave, all in gypsum, Western Ukraine. Photo by the author.

in artesian transverse caves, leaving characteristic morphologies that include ceiling cupolas, roof pendants and ceiling half-tubes. The latter, formed by buoyant currents, sometimes can be continuously traced from feeders to outlet domes (Fig.6). Such forms are particularly common in gypsum caves and hydrothermal caves.

10. Clastic cave sediments are represented mainly by fine clays and silts. These can be partly autochthonous (comprising insoluble residues) although most of them are allochthonous sediments brought into artesian systems from overlying formations only during the late artesian stages, mainly via breakdown structures. Sediments are fine-grained, uniformly distributed and display similar facies even on a scale of a large cave system.

11. Caves are barren of common infiltration speleothems unless the protective caprock (former confining bed) is largely or entirely stripped. Speleothems, although not inevitably, include "exotic" hydrothermal minerals, or minerals deposited as the products of redox reactions that are typical in the transitional zones.

\section{SELECTED EXAMPLES OF CAVES FORMED BY TRANSVERSE SPELEOGENESIS}

Artesian basins containing carbonate and sulfate formations within the upper zone of active circulation are widespread throughout cratonic and foreland regions. Intrastratal karst in confined settings is much more common than is commonly believed. However, artesian caves become accessible only when artesian aquifer systems are breached by subaerial erosion processes and at least partly drained. Even when explored, artesian caves were commonly misinterpreted in the frames of conventional speleogenetic theories, partly because there was no established concept of artesian speleogenesis. Adoption of the transverse speleogenesis concept requires revisiting of conventional views on the origin of many caves, which display uniform passage morphology and/or maze patterns. Selected examples referred to below include both caves for which the origin under discussion is well established and caves which can be suspected of this origin on the basis of criteria listed above.

In the Prichernomorsky artesian basin, in the southern Ukraine, particularly beneath Odessa City, 

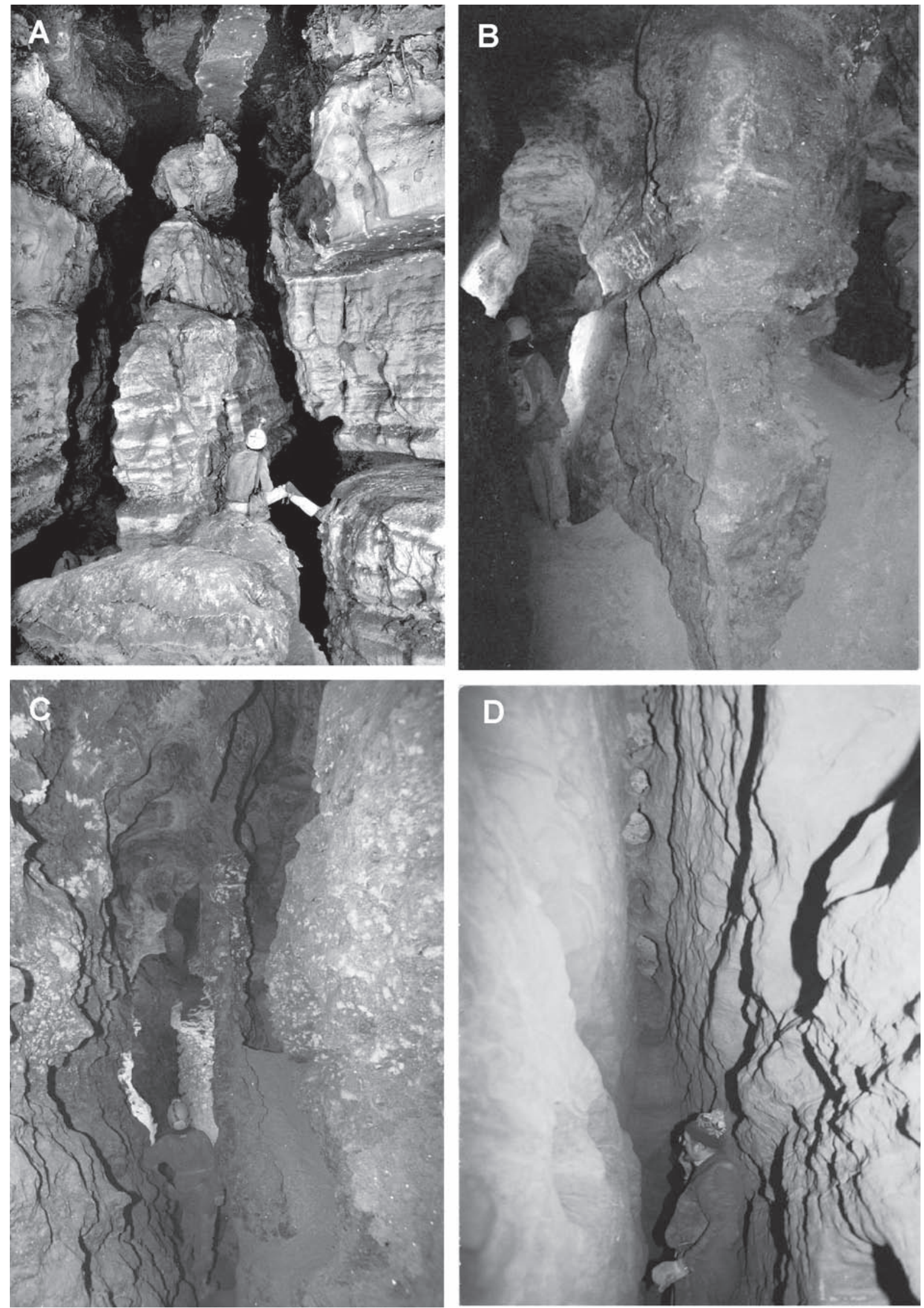

Fig. 9. Typical fissure-like passages in artesian maze caves. A - Wind Cave in limestones, South Dakota; B - Slavka Cave in gypsum, Western Ukraine; C - Mlynki Cave in gypsum, Western Ukraine; D - Fuchslabyrinth Cave in limestone, Germany. Photo A by Arthur Palmer; B, C and D by author. 
many small caves are intersected by extensive old limestone mines in a single limestone bed within the carbonate sequence of Miocene age, a drained part of the regionally extensive artesian system. They represent isolated slot-like passages or several intersecting passages, the longest cave being a relatively small maze with 1400 m of mapped passages (Fig.11IB). These caves are probably the most unambiguous example of transverse speleogenesis: all passages but few "transit" ones laterally terminate as narrow (1$10 \mathrm{~cm}$ ) apparently declining fissures (Pronin, 1995). Similarly, mines in the Tertiary gypsum beds in the Paris artesian basin encounter caves that fit to the transverse category by several criteria (Fig. 11-III) (Beluche et al., 1996).
The world's foremost examples of artesian transverse speleogenesis are the giant mazes in the Miocene gypsum in the Western Ukraine and in the Mississippian Madison limestones in the Black Hills, South Dakota, USA (Fig. 12). They are 3-dimentional (multi-storey) rectilinear, network mazes, and are some of the longest caves in the world. Although an artesian transverse origin for the Ukrainian gypsum caves is well established (Klimchouk, 1992, 1997, $2000 b)$, the origin of the Black Hills caves is still debatable (Palmer and Palmer, 2000a). They meet all criteria listed above and, in the present author's opinion, can be adequately described by the model presented here. Discussion provided by Ford (1989) supports this interpretation.

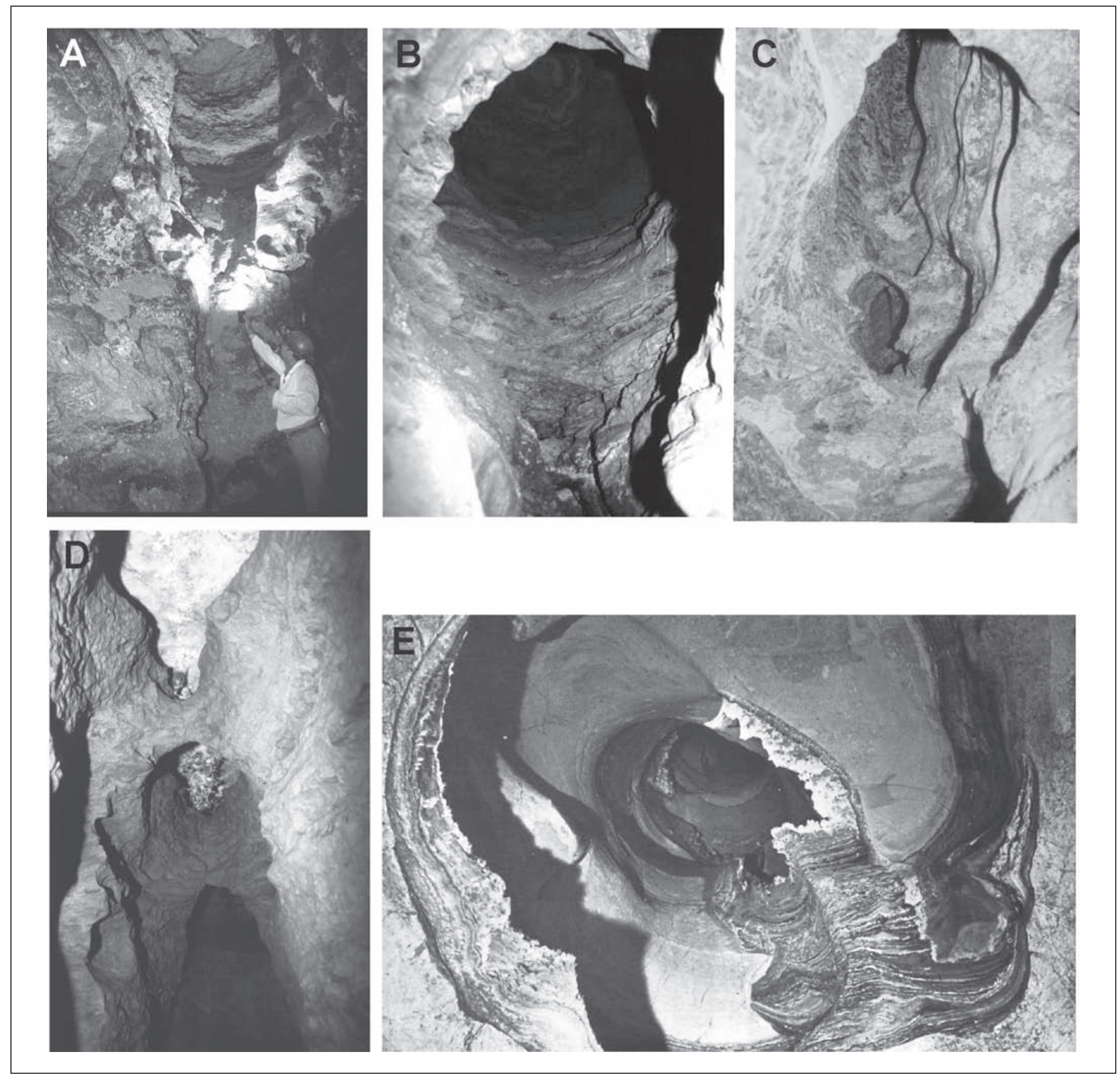

Fig. 10. Examples of outlet domes and cupolas from artesian caves (views upward). A and B - Mlynki Cave, and C - Optymistyshna Cave in gypsum, Western Ukraine. D - Fuchslabyrinth Cave in limestone, Germany. E - Wind Cave in limestone, South Dakota. Photo A through D by the author, photo E by Arthur Palmer. 
The great artesian basins of the North America offer suitable conditions for artesian transverse speleogenesis. The origin of many now relict network caves, previously interpreted in different ways, can probably be revisited in terms of the artesian transverse model. Huntoon (2000) gives good examples of confined karstification and network maze patterns in the lower Paleozoic Redwall-Muav aquifer.

Similarly, great artesian basins of the EasternEuropean craton and Siberia provide many examples of artesian transverse speleogenesis. In the former region, the best known are the gypsum mazes in its south-western (Western Ukraine) and eastern (foreUral) outskirts. In Siberia, the remarkable example is $57 \mathrm{~km}$-long two-dimensional network maze of Botovskaja cave, developed in a Lower Ordovician limestone bed sandwiched between sandstone aquifers (Filippov, 2000; Fig.13A). The area is now an open and drained part of the Angaro-Lensky artesian basin.

In Western Europe the most unambiguous examples, known to the author, of caves sharing the artesian transverse origin are network caves Fuchslabyrinth (6400m; Baden-Würtenberg, Germany; Fig.13B) (Muller et al., 1994), Moestroff (4000m; Luxembourg; Fig.13C) in the Muschelkalk limestones (Massen, 1997), and Knock Fell Caverns (4000m) in the Carboniferous limestones of the Northern Pennies, UK (Fig.13D). In addition to favourable lithostratigraphy and tight-packed fissure-controlled pattern of these caves, the "transverse" origin of these caves is strongly supported by the presence of clear feeders and outlet cupolas through labyrinths. Many similar network mazes are found in the Northern Pennies (Ryder, 1975), some of them encountered by mines. Another characteristic example of this type of speleogenesis in Europe is Estremera Cave in Neogene gypsum of the Madrid Basin, Spain (Almendros \& Anton Burgos, 1983), where a pattern of feeder and outlet features is well recognisable throughout the labyrinth.

The artesian transverse speleogenesis model has been recently applied to interpret the origin of network mazes and "halls-and-narrows" morphology common in eastern Australia (Osborne, 2001). Osborne pointed to many features that conform to the above criteria of "uprising" transverse speleogenesis, disregarded the possibility of the origin of those mazes due to downward recharge through the caprock and concluded that they may have developed by the upward recharge from basal aquifers. It should be noted that regular variations in size and morphology between passages, which are guided by different sets of joints in the network (described by Osborne as the "hallsand-narrows" morphology), are common in almost all cases referred to in this section (particularly in the Western Ukraine and South Dakota; in Botovskaya, Fuchslabyrinth, Knock Fell Caverns, Estremera caves etc).

A few papers describing karst and caves in Saudi Arabia, Qatar and other regions of the Arabian Peninsula (i.e. Peters et al., 1990; Sadiq \& Nasir, 2002) give strong evidence in favour of artesian origin of karst features, although not interpreting karst features in this way. The vast regional artesian

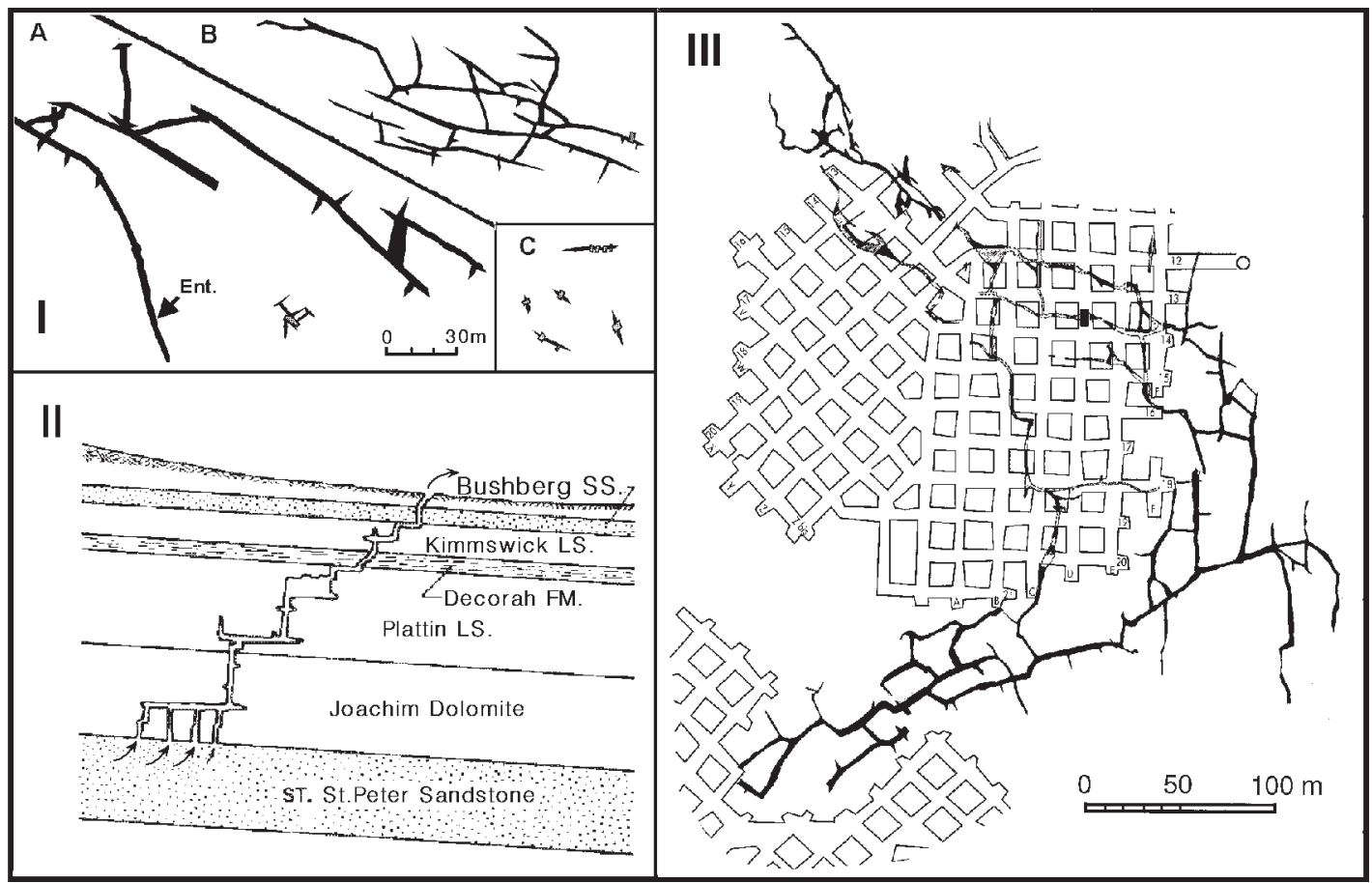

Fig. 11. Typical morphologies of caves formed by transverse flow across soluble beds: $I=$ isolated single passages and small clusters of connected passages encountered by mines in the Prichernomorsky artesian basin, south Ukraine (From Pronin, 1995), II = fissure-like caves and ascending pits in eastern Missouri (From Brod, 1964), III = the Denis Parisis gypsum cave encountered by a mine in the Paris artesian basin (From Beluche et al., 1996). 


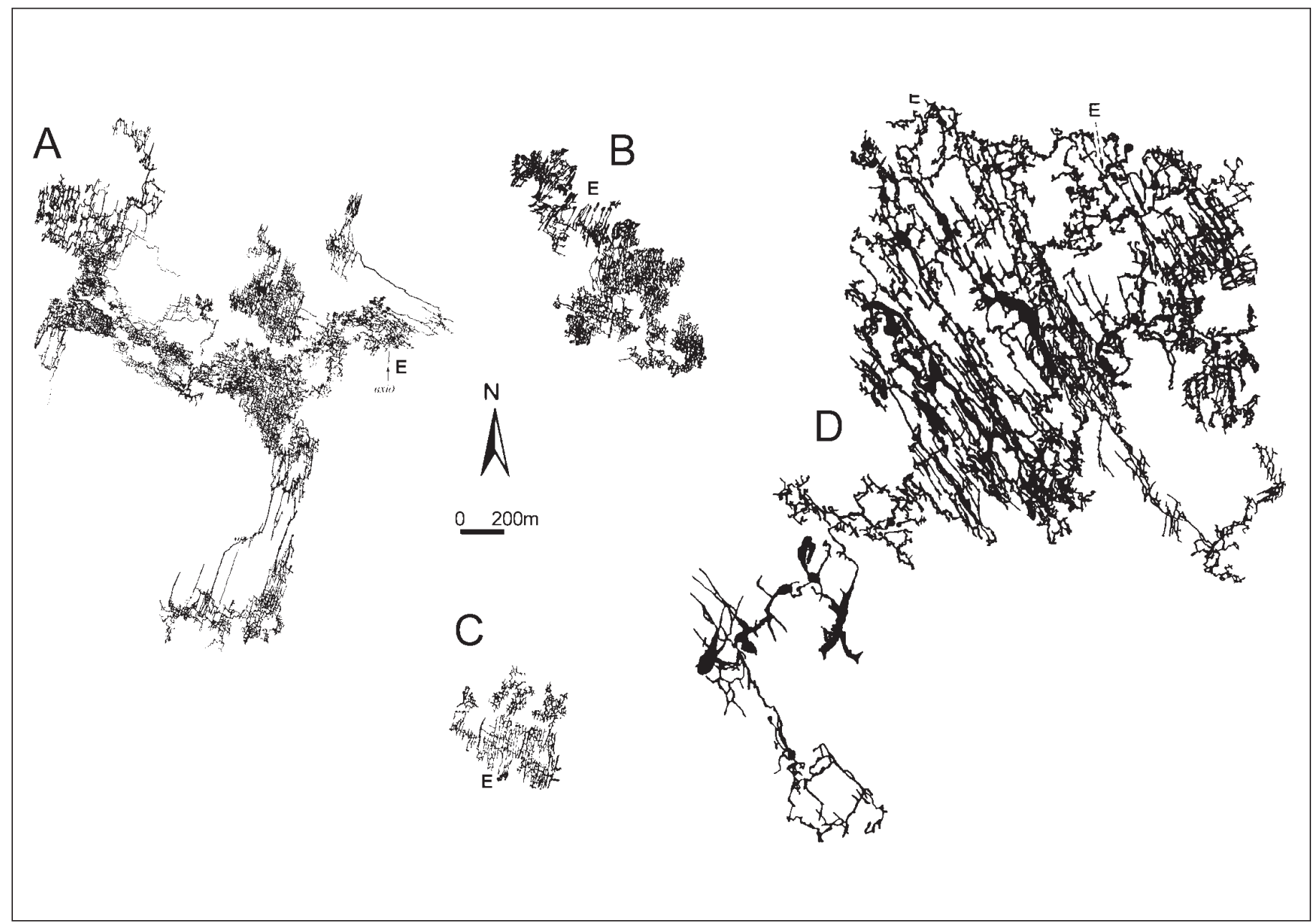

Fig. 12. Typical patterns of maze caves, brought to approximately same scale: A - Optymistychna Cave (214km), B - Ozerna Cave (117km), C - Kristal'na Cave (24km), all in gypsum, Western Ukraine. D - Wind Cave in limestone, South Dakota (129km).

system comprises alternating sulfate, carbonate and terrigenous beds within the Arab, Hith, Silaiy, Aruma, Umm Ar Radhuma, Rus and Dammam formations. This offers very suitable conditions for transverse speleogenesis. Numerous caves are mainly fissureand slot-like passages or clusters of passages ("ghar" caves), some are clear rectilinear mazes. The regional artesian system discharges via numerous springs at the Gulf area, many of them being vertical pits ("ayns") through which groundwater rises from horizontal passage clusters at the base (Hötzl et al., 1978). Numerous deep collapse sinkholes with unexplored caves at the base, described in the region, are likely to be related to regionally operating contemporary artesian speleogenesis rather than to presently inactive cave systems formed during past epochs of humid climates.

A good example of vertically extended transverse speleogenesis was given by Brod (1965; Fig. 11-II) from eastern Missouri. Rectilinear fissure caves and small maze clusters, developed along the bottom of the soluble unit by the ascending recharge from the basal sandstones, continue upward with a succession of pits and passages which breach the upper beds of varying lithologies and eventually provide focused discharge outlets for the artesian aquifer.

Similar origin could be assigned to Magharet
Qasir Hafeet Cave in the Jebel Hafeet ridge in the United Arab Emirates, described by Waltham \& Fogg (1998). The cave has rift-like passages at the depths of almost $100 \mathrm{~m}$, connected to the surface through a series of vertical joints and shafts of apparently uprising morphology. It occurs at the crest of an eroded anticline, in limestones that were confined by a clay-marl sequence in the past. Although initially a conventional phreatic origin was suggested for this cave (Waltham \& Fogg, 1998), the possibility of per ascensum hydrothermal origin has been later acknowledged (Waltham \& Jeannin, 1998).

The specific speleogenetic environment, paragenetic or sequential to artesian, is created by settings of marginal outflow from artesian basins to the adjacent massifs, the best examples being the Guadalupe Mountains, USA (Carlsbad Cavern, Lechuguilla and other caves) and Kugitang Mountains in Turkmenistan (Cupp-Coutunn system and other caves in the area). The cave-forming flow pattern was ascending and cross-formational, so that these cases broadly fit to the transverse speleogenesis model. Cross-formational flow favoured the mixing of H2S bearing waters with oxygenated meteoric waters, which is believed to be the main source of aggressiveness (Hill, 2000; Palmer $\&$ Palmer, 2000b). These caves have complex patterns consisting of ramifying irregular rooms and network 


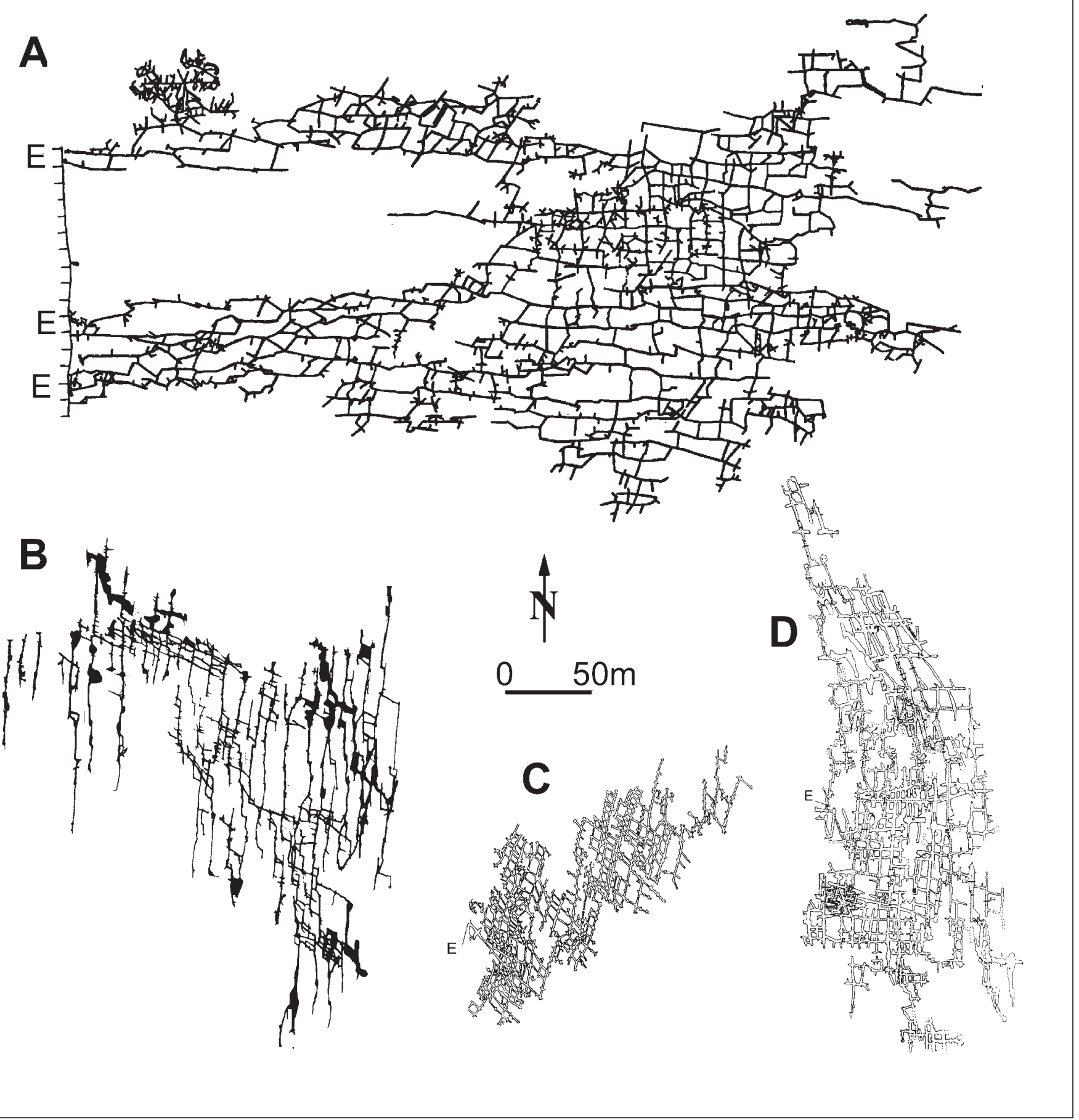

Fig. 13. Typical patterns of maze caves, brought to approximately same scale: A - Botovskaya Cave (57km), Siberia, Russia; B - Fuchslabyrinth Cave (6.4km), Germany; C - Moestrof Cave (4km), Luxembourg; D - Knock Fell Cavern (4km), UK.

and spongework mazes at various intervals within great vertical range. Such combination can be explained, in addition to hydrochemical reasons (Palmer \& Palmer, $2000 b)$ by varying structural conditions in different stratigraphic intervals causing either localised or dispersed mode of cross-formation flow, and by semiconfined conditions at different levels due to vertical heterogeneity of initial permeability.

\section{COMPARISON OF CONFINED VERSUS UNCONFINED CONDUIT POROSITY}

The distinctions between confined and unconfined speleogenesis can be illustrated by the analysis of morphometric parameters of typical cave patterns. Klimchouk (2003) compared two representative samples of typical cave systems formed in the respective settings. The sample that represents unconfined speleogenesis consists of solely limestone caves, whereas gypsum caves of this type tend to be less dendritic. The sample that represents confined speleogenesis consists of both limestone and gypsum maze caves.

Passage network density (the ratio of the cave length to the area of the cave field, $\mathrm{km} / \mathrm{km} 2$ ) is one order of magnitude greater in confined settings than in unconfined (average $167.3 \mathrm{~km} / \mathrm{km} 2$ versus $16.6 \mathrm{~km} /$ 
$\mathrm{km} 2$ ). Similarly, an order of magnitude difference is observed in cave porosity (a fraction of the volume of a cave block, occupied by mapped cavities; $5.0 \%$ versus $0.4 \%$ ). This illustrates that storage in maturely karstified confined aquifers is generally much greater than in unconfined. Average areal coverage (a fraction of the area of the cave field occupied by passages in a plan view) is about 5 times greater in confined settings than in unconfined $(29.7 \%$ versus $6.4 \%)$. This means that conduit permeability in confined aquifers is appreciably easier to target with drilling than the widely spaced conduits in unconfined aquifers.

\section{VARIABILITY IN AQUIFER CHARACTERISTICS AND BEHAVIOUR RESULTED FROM UNCONFINED AND CONFINED SPELEOGENESIS}

The specific mechanism of artesian transverse speleogenesis is responsible for the peculiar features of conduit porosity that develop in soluble formations under confined settings. This gives rise to characteristic distinctions between karst systems that develop in unconfined and confined karst aquifers. Various researchers noted many of these distinctions in different years, although controversies with artesian speleogenesis discussed earlier inhibited their adequate interpretation and summarisation. Huntoon (2000) provided an illustrative comparison of features found in unconfined and confined aquifers in Arizona. The summary that follows is based on the above discussion (see also Klimchouk, 1997, 2000a) and the mentioned work of Huntoon.

Caves formed in unconfined settings tend to form highly localised linear or dendritic systems that account for high heterogeneity and extreme anisotropy of unconfined karst permeability. They receive more or less concentrated recharge from the immediately overlying or adjacent areas, with which they have genetic relations. Conduit systems are hierarchically organised to effectively concentrate and laterally transmit flow (and hence contaminants) in the downgradient direction. This organisation is frequently cited to be similar to surface water drainage networks. Storage is commonly low in karst aquifers that evolved in unconfined settings. System responses to major storm events are characterised by flow-through hydraulics. Spring discharge from unconfined conduit systems tends to be flashy and highly variable.

Caves formed in confined settings tend to be 2-D or multi-storey mazes, in which conduits are broadly uniform and densely packed. Maze systems evolve to facilitate transverse hydraulic communication between common aquifers across the soluble units. They receive diffuse recharge from an adjacent aquifer, most typically from the underlying one, and they do not have direct genetic relations with the overlying surface. This type of karstification commonly results in more isotropic conduit permeability pervasively distributed within highly karstified areas measuring up to several $\mathrm{km} 2$. Localisation of such areas depends on distribution of head gradients in the layered artesian system (which is partly guided by erosional topography), and also on regional heterogeneities in vertical hydraulic conductivity of various beds in the system. Although being laterally integrated throughout conduit clusters, confined conduit systems, however, do not transmit flow laterally for considerable distances nor concentrate it. White (1988) fittingly compared organisation of artesian maze systems with swamp hydrology.

Huntoon (2000) noticed that well-developed artesian karst porosity and storage in karst aquifers behave similarly to their counterparts in porous media, with the distinction that "pores" are very large. Ubiquitous conduit porosity that develops through areas of transverse speleogenesis accounts for rather high aquifer storage. Discharge of artesian karst springs is commonly very steady, being moderated by high karstic storage developed in soluble units and by the hydraulic capacity of a whole artesian system.

\section{CONCLUSIONS}

The long-lasting discussion of the possibility of the artesian origin of maze caves can be satisfactory resolved on the basis of the proper recognition of crossformational hydraulic communication in artesian basins, and by the concept of transverse speleogenesis. Adoption of these views bypasses the major problem that existed in interpreting artesian speleogenesis, i.e. limited hydraulic and hydrochemical cave-forming capability of the "classic" lateral artesian flow.

There is a specific hydrogeologic mechanism inherent in artesian transverse speleogenesis (restricted input/output) that suppresses the positive flow-dissolution feedback and hence speleogenetic competition in fissure networks, and accounts for the development of more pervasive channelling in confined settings, of maze patterns where appropriate structural prerequisites exist. This is the fundamental cause for the distinctions between cave morphologies evolving in unconfined and confined aquifers, and for eventual distinctions of karstic permeability, storage characteristics and flow system behaviour between the two types of aquifers.

Recognition of the differences between origin, organisation and behaviour of karst systems evolved in unconfined and confined settings can improve efficiency of exploration and management of various resources in karst regions and adequacy of assessment of karst-related hazards.

\section{ACKNOWLEDGEMENTS}

The author is indebted to Prof. Derek Ford and Prof. Art Palmer for their inspiration and help in preparation of previous publications on this topic, to Dr. Armstrong Osborne for his help in improving English of this paper, to John Sheltens (USA), Sergio Garsia Dils (Spain), Dr. John Lamont-Black (UK), Ralph Müller, Wolfgang Pikart and Graham Hash (Germany), and members of the Speleo-Club of Luxembourg for arranging my field visits in various periods to remarkable artesian mazes of Wind and Jewel caves, Estremera, Knock Fell Caverns, Moestroff and Fuchslabyrinth caves. Thanks 
go to many Ukrainian speleologists who over the years assisted in studying the great gypsum mazes of the Western Ukraine.

\section{REFERENCES}

Almendros M.A., Anton Burgos F.J., 1983 - El complejo karstico-yesifero subterraneo "Pedro Fernandes" (Estremera, Provincia de Madrid). In: Vidal Romani J.R. and Vilas Martin F. (Eds), VI Reunion da Grupo Espanol de Traballo de Quaternario: 333-341.

Bakalowicz M.J. et. al., 1987 - Thermal genesis of dissolution caves in the Black Hills, South Dakota. Bull. Geol. Soc. Amer. 99, 729-738.

Beluche F., Kens J. and Teyssier D., 1996 - Le reseau Denis Parisis, Bethemont-la-Foret, Val-d'Oise. Spelunca, 63, 31-37.

Birk S., 2002 - Characterisation of karst systems by simulating aquifer genesis and spring responses: Model development and application to gypsum karst. Tubingen Geowissenschaftliche Arbeiten, Reine C, 60. Tubingen, 118 p.

Birk S., Liedl R., Sauter M., Teutsch G., 2003 - Hydraulic boundary conditions as a controlling factor in karst genesis: A numerical modelling study on artesian conduit development in gypsum. Water Resour. Res., 39 (1): 1004, doi: 10.1029/2002WR001308.

Brod L.G., 1964 - Artesian origin of fissure caves in Missouri. NSS Bulletin, 26 (3): 83-114.

Clemens T., Huckinghaus D., Sauter M., Liedl R., Teutsch G. 1997 - Simulation of the evolution of maze caves. Proceedings, 12th International Congress of Speleology vol. 2, La Chaux-de-Fonds, Switzerland: 65-68.

Dreybrodt W., 1990 - The role of dissolution kinetics in the development of karst aquifers in limestone: A model simulation of karst evolution. Journal of Geology, 98 (5): 639-655.

Dreybrodt W., Gabrovsek F., 2002 - Basic processes and mechanisms governing the evolution of karst. In: Gabrovsek, F. (Ed.), Evolution of karst: from prekarst to cessation. Postojna-Ljubljana: Zalozba ZRC, 115154. (Also published in the Journal of Speleogenesis and Evolution of Karst Aquifers 1 (1), 2003, www.speleogenesis.info 26 pages).

Dublyansky Y. V. 2000 - Hydrothermal Speleogenesis in the Hungarian Karst. In: Klimchouk A., Ford D., Palmer A. and Dreybrodt W. (Eds), Speleogenesis: Evolution of Karst Aquifers. Huntsville: National. Speleological Society: 298-303.

Dumont K. A., Rajaram H., Budd D. A., 1999 - The initiation of hypogene caves in fractured limestone by rising thermal water: investigation of a parallel series of competing fractures. In: Palmer, A.N., Palmer, M.V. and Sasowsky, I.D. (Eds), Karst Modeling: Special Publication 5, Charles Town, West Virginia (USA): The Karst Waters Institute, 132.

Elliot T., 1994 - Knock Fell Caverns, Cumbria: Cave conservation plan. E/N Ref: F72-05-44. Adas, UK.

Filippov A.G., 2000 - Speleogenesis of the Botovskaya Cave, Eastern Siberia, Russia. In: Klimchouk A., Ford D., Palmer A. and Dreybrodt W. (Eds), Speleogenesis: Evolution of Karst Aquifers. Huntsville: National. Speleological Society: 282-286.
Ford D.C., 1971 - Geologic structure and a newexplanation of limestone cavern genesis. Trans. Cave Res. Gr., G.B., 13 (2): 81-94.

Ford D.C., 1988 - Characteristics of dissolutional cave systems in carbonate rocks. In: James, N.P. and Choquette, P.W. (Eds), Paleokarst. New York: SpringerVerlag: 25-57.

Ford D.C., 1989 - Features of the genesis of Jewel Cave and Wind Cave, Black Hills, South Dakota. NSS Bulletin, 51: 100-110.

Girinsky N.K., 1947 - Some questions of groundwater dynamics. Hidrogeologija i Inzhenernaja Geologija, 9: 27-32.

Glennie E.A., 1954 - Artesian flow and cave formation. Trans. Cave Res. Group Gr. Br., 3: 55-71.

Groves C. G., Howard A. D., 1994 - Early development of karst systems. 1. Preferential flow path enlargement under laminar flow. Water Resources Research, 30: $2837-2846$.

Hill C.A., 2000 - Sulfuric acid, hypogene karst in the Guadalupe mountains of New Mexico and West Texas, USA. In: Klimchouk A., Ford D., Palmer A. and Dreybrodt W. (eds.), Speleogenesis: Evolution of Karst Aquifers. Huntsville: National. Speleological Society: 309-316.

Hötzl H., Maurin V., Zotl J.G., 1978 - Geologic history of the Al Hasa area since the Pliocene. In: Al Sayari S.S. and Zotl J.G. (Eds.), Quaternary period in Saudi Arabia. Wein: Springer-Verlag: 58-77.

Howard A.D., 1964 - Model for cavern development under artesian ground water flow, with special reference to the Black Hills. NSS Bulletin, 26: 7-16.

Howard A.D., Groves C.G., 1995 - Early development of karst systems. 2. Turbulent flow. Water Resources Research, 31 (1): 19-26.

Huntoon P.W., 1993 - The influence of Laramide foreland structures on modern ground-water circulation in Wyoming artesian basins. In: Snoke A.W., Steidtmann J.R. and Roberts S.M. (Eds.), Geology of Wyoming. Geological Survey of Wyoming Memoir No.5: 756-789.

Huntoon P.W., 1996 - Large-basin groundwater circulation and paleo-reconstruction of circulation leading to uranium mineralization in Grand Canyon breccia pipes, Arizona. The Mountain Geologist, 33 (3): 71-84.

Huntoon P. W., 2000 - Variability of karstic permeability between unconfined and confined aquifers, Grand Canyon region, Arizona. Environmental and Engineering Geoscience VI (2): 155-170.

Jennings J.N., 1971 - Karst. The M.I.T. Press. 252 p.

Klimchouk A.B., 1990 - Artesian genesis of the large maze caves in the Miocene gypsum of the Western Ukraine. Doklady Akademii Nauk Ukrainskoj SSR ser. B 7: 28-32. (Russian, res. Engl.).

Klimchouk A.B., 1992 - Large gypsum caves in the Western Ukraine and their genesis. Cave Science 19 (1): 3-11.

Klimchouk A.B., 1994 - Speleogenesis under confined conditions, with recharge from adjacent formations. Comptes Rendus du ColloqueInternationalde Karstology a Luxembourg, Publ. Serv. Geol. Luxembourg, 27: 85-95.

Klimchouk A.B., 1997 - Artesian speleogenetic setting. 
Proceedings of the 12th International Congress of Speleology, vol.1, La Chaux-de-Fonds, Switzerland: 157-160.

Klimchouk A.B., 2000a - Speleogenesis under deepseated and confined settings. In: A. Klimchouk, D. Ford, A. Palmer, W. Dreybrodt (Eds), Speleogenesis: Evolution of karst aquifers. Huntsville: Natl. Speleol. Soc.: 244-260.

Klimchouk A.B., 2000b - Speleogenesis of great gypsum mazes in the Western Ukraine. In: A. Klimchouk, D. Ford, A. Palmer, W. Dreybrodt (Eds), Speleogenesis: Evolution of karst aquifers. Huntsville: Natl. Speleol. Soc.: 261-273.

Klimchouk A.B., 2003 - Unconfined versus confined speleogenetic settings: variations of solution porosity. Journal of Speleogenesis and Evolution of Karst Aquifers 1 (2), 2003,www.speleogenesis.info, 7 p.

Klimchouk A.B., Andrejchouk V.N., Turchinov I.I., 1995 - Structural pre-requisites of speleogenesis in gypsum in the Western Ukraine. Kiev: Ukrainian Speleol. Assoc.: 104 p. (Russian and English).

Lowe D.J., 1992 - The origin of limestone caverns: an inception horizon hypothesis. Ph.D. Thesis, Manchester Metropolitan University.

Massen F. (Ed.), 1997 - The Moestroff Cave: A study of the geology and climate of Luxembourg's largest maze cave. Centre de recherche public - Centre Universitaire Luxemburg: 200 p.

Mjatiev A.N., 1947 - Confined complex of underground waters and wells. Izvestija AN SSSR, otd. tekhnich. nauk, 9: 33-47. (in Russian).

Müller R., Nething M., Rathgeber T., 1994 - Über das Fuchslabyrinth und die benachbarten Spaltenhöhlen bei Schmalfelden (Gemende Schrozberg, Landkreis Schwäbisch Hall). Beiträge zur Höhlen- und Karstkunde in Südwestdeutschland, 37: 1-19.

Osborne R.A.L., 2001 - Halls and narrows: Network caves in dipping limestones from eastern Australia. Cave \& Karst Science, 28 (1): 3-14. (Also published in the Journal of Speleogenesis and Evolution of Karst Aquifers 1 (1), 2003, www.speleogenesis.info, 14 pages).

Palmer A.N., 1975 - The origin of maze caves. NSS Bulletin, 37 (3): 56-76.

Palmer A.N., 1991 - Origin and morphology of limestone caves. Geol. Soc. Am. Bull., 103: 1-21.

Palmer A.N., 1984 - Geomorphic interpretation of karst features. In: LaFleur R.G. (Ed.), Groundwater as a geomorphic agent. Boston: Allen \& Unwin: 173-209.

Palmer A.N., 1995 - Geochemical models for the origin of macroscopic solution porosity in carbonate rocks. In: Budd A.D., Saller A.H. and Harris P.M. (Eds.), Unconformities and porosity in carbonate strata. AAPG Memoir, 63, Tulsa, Oklahoma: 77-101.

Palmer A. N., 2000a - Hydrogeologic control of cave patterns. In: Klimchouk A., Ford D., Palmer A. and
Dreybrodt W. (eds.), Speleogenesis: Evolution of Karst Aquifers. Huntsville: National. Speleological Society: 77-90.

Palmer A.N., 2000b - Digital modelling of individual solution conduits. In: Klimchouk A., Ford D. C., Palmer A. N. and Dreybrodt W. (Ed.), Speleogenesis. Evolution of karst aquifers. Huntsville: Natl. Speleol. Soc.: 194-200.

Palmer A. N., 2000c - Maze origin by diffuse recharge through overlying formations. In: Klimchouk A., Ford D., Palmer A. and Dreybrodt W. (Eds.), Speleogenesis: Evolution of Karst Aquifers. Huntsville: National. Speleological Society: 387-390.

Palmer A.N., 2002 - Speleogenesis in carbonate rocks. In: Gabrovsek F. (Ed.), Evolution of karst: from prekarst to cessation. Postojna-Ljubljana: Zalozba ZRC: 4360. (Also published in the Journal of Speleogenesis and Evolution of Karst Aquifers 1 (1), 2003, www.speleogenesis.info, 11 pages).

Palmer A. N., Palmer M. V., 2000a - Speleogenesis of the Black Hills maze caves, South Dakota, USA. In: Klimchouk A., Ford D. C., Palmer A. N. and Dreybrodt W. (Eds.), Speleogenesis. Evolution of karst aquifers. Huntsville: National Speleological Society: 274-281.

Palmer A.N., Palmer M.V., 2000b - Hydrochemical interpretation of cave patterns in the Guadalupe Mountains, New Mexico. Journal of Cave and Karst Studies, 62 (2): 41-58.

Peters W.D., Pint J., Kremla N., 1990 - Karst landforms in the Kingdom of Saudi Arabia. The NSS Bulletin, 52: 21-32.

Pronin K.K., 1995 - Karst caves in the Odessa region. Dep. Paper No.953 UK95 (Ukraine): 42 pp. (in Russian).

Ryder P.F., 1975 - Phreatic neetwork caves in the Swaledale area, Yorkshire. British Cave Research Association Transactions, 1: 101-124.

Sadiq A.M., Nasir S. J., 2002 - Middle Pleistocene karst evolution in the state of Qatar, Arabian Gulf. Journal of Karst and Cave Studies, 64 (2): 132-139.

Shestopalov V.M., 1981 - Natural resources of underground water of platform artesian basins of the Ukraine. Kiev: Naukova Dumka: 195 p. (Russian).

Shestopalov V.M., 1988 - Methods of study of underground water natural resources. Moscow: Nedra, 168 p. (Russian).

Töth J., 1995 - Hydraulic continuity in large sedimentary basins. Hydrogeology Journal, 3 (4): 4-15.

Waltham T., Fogg T., 1998 - Limestone caves in Jebel Hafeet, United Arab Emirates. Cave and Karst Science, 25 (1): 15-22.

Waltham T., Jeannin P-Y., 1998 - Caves in the United Arab Emirates. Cave and Karst Science, 25 (3): 149.

White W.B., 1969 - Conceptual models for carbonate aquifers. Ground Water, 7: 15-21.

White W.B., 1988 - Geomorphology and hydrology of karst terraines. Oxford: Oxford University Press: 464 p. 